\title{
Identifying Patient Strengths Instruments and Examining Their Relevance for Chronic Disease Management: A Systematic Review
}

\author{
Deshira D. Wallace, $\mathrm{PhD}^{1}$; Ruchir N. Karmali, $\mathrm{PhD}^{1,2}$; Christine Kim, $\mathrm{PhD}^{1}$; Ann Marie White, EdD ${ }^{3,4}$; \\ Kurt C. Stange, MD, $\mathrm{PhD}^{5}$; Kristen Hassmiller Lich, $\mathrm{PhD}^{1}$
}

\begin{abstract}
Accessible Version: www.cdc.gov/pcd/issues/2021/20_0323.htm
Suggested citation for this article: Wallace DD, Karmali RN, Kim C, White AM, Stange KC, Lich KH. Identifying Patient Strengths Instruments and Examining Their Relevance for Chronic Disease Management: A Systematic Review. Prev Chronic Dis 2021;18:200323. DOI: https://doi.org/10.5888/pcd18.200323.
\end{abstract}

\section{PEER REVIEWED}

\section{Summary}

What is already known on this topic?

Chronic disease management often focuses on what is wrong with patients rather than recognizing their strengths and resources. However, studies show the value of emphasizing personal strengths to improve outcomes.

\section{What is added by this report?}

How instruments evaluate personal strengths varies, making it especially difficult when determining the use of instruments in clinical populations. This systematic review defines the heterogeneity of constructs that research has used to examine personal strengths as well as the reliability and validity of strengths-related scales.

What are the implications for public health practice?

Understanding the value of these various scales can inform public health, and specifically primary care practice, to improve the care of adults managing 1 or more chronic conditions.

\section{Abstract}

\section{Introduction}

Most health care focuses on patients' deficits to encourage behavior change. A strengths-based approach, which relies on identifying patient strengths, has great potential to facilitate behavior change for chronic disease management. Little is known about instruments used to assess patient strengths. We conducted a systematic review to identify validated instruments that assess personal strengths by using a theory elaboration approach.

\section{Methods}

We searched 8 databases including Web of Science, Cumulative Index of Nursing and Allied Health (CINAHL), and PsycINFO (through July 2019) to identify peer reviewed, English-language studies that described strength-based instruments. Thereafter, we evaluated the validity and reliability of the instruments according to 18 Scientific Advisory Committee of the Medical Outcome Trust (SACMOT) criteria, and used an inductive, iterative editing process to identify constructs measured by the instruments.

\section{Results}

We identified 26 instruments that met our inclusion criteria. The instruments were validated in various clinical and nonclinical populations. Only 4 instruments met most of the SACMOT criteria for validation. We extracted 91 unique constructs that fell into 3 domains: inner strengths (49), external strengths (13), and personality constructs (29).

\section{Conclusion}

A limited number of reliable and valid instruments are available to assess strengths for the adult population, particularly for clinical populations. Internal strengths can be leveraged to improve patient health; however, the development and validation of additional instruments to capture personal strengths is necessary to examine the multilevel influence of external strengths on individual behaviors and well-being.

\section{Introduction}

Approximately half of all US adults have 1 or more diagnosed chronic conditions, such as diabetes, heart disease, and arthritis (1). In 2016, the direct health care cost associated with chronic health conditions was $\$ 1.1$ trillion dollars (2). Chronic conditions can be managed successfully by changing unhealthy behaviors (3-7). Patients, with their care team, can identify strategies and leverage skills to regulate behaviors (4). A strengths-based ap- 
proach to chronic disease management can support selfmanagement and behavior change.

The strengths-based approach emerged from the social work field and counteracts the deficit-based approach from the health science professions. A deficit-based approach focuses on what is wrong with patients rather than recognizing their strengths and resources (8). The strengths-based approach assumes that individuals have the capacity to grow, do the best they can, and know what is best for them (8). Strengths include personal attributes such as faith, use of humor, flexibility; interpersonal assets such as friends or family who can be called on for help; and external resources such as ability to access community resources for health. Whereas deficit-based approaches to chronic disease management focus on patients' problems and behavioral shortcomings (eg, focusing on patient challenges in engaging with recommended behaviors), Rotegård et al (9) defined patient strengths, or health assets, as "the repertoire of potentials - internal and external strength qualities in the individual's possession, both innate and acquired that mobilize positive health behaviors and optimal health/wellness outcomes." In practice, the care team works with a patient to identify their inherent strengths and the patient uses these strengths to promote recovery and well-being (10). The strengthsbased approaches in counseling and case management are associated with an improvement in depressive symptoms, substance use behaviors, and postsurgery recovery by improving key determinants such as perceived patient empowerment $(3,5,9,11-13)$.

Implementing a strengths-based approach relies on identifying a patient's strengths (14-17). However, eliciting a patient's strengths informally is challenging during time-constrained clinical visits (18). A formal strengths elicitation approach is needed to provide the structure during clinic visits to support patients in suggesting strengths to leverage (16). A concept analysis developed a theoretical framework for patient strengths (9); however, this framework was based on health assets in nursing care of cancer patients. Little is known about how patient strengths are operationalized as a construct in existing validated assessments - either broadly or among noninstitutionalized or community-based populations that frequent health care to manage a chronic condition (ie, clinical populations). Moreover, the construct of personal strengths has not been clearly defined in the literature, which could result in difficulties in distinguishing constructs from each other and instruments that may not adequately capture or sufficiently reflect the phenomenon.

The objective of our study was to identify and systematically summarize constructs that measure dimensions of personal strengths. Specifically, we were interested in understanding what we know about personal strengths and the extent to which instruments that measure personal strengths are validated for application in chron- ic care management. We reviewed instruments for measuring personal strengths by using the process of theory elaboration, to make a theoretical contribution in the field through specification of the aspects of the broad construct of personal strengths. The process of theory elaboration uses an existing model or conceptual idea as the basis for developing new theoretical insights, through contrasting, specifying, or structuring theoretical constructs to improve our understanding of the measurement of personal strengths (19). Although only a limited number of scales are specifically related to chronic disease management, examining currently validated scales that have been used in adults more broadly can provide information on what constructs and scales can be applied in populations that are managing chronic conditions. The results can inform the use of strengths-based scales in clinic settings for populations managing chronic conditions.

\section{Methods}

Personal strengths is a broad construct; therefore, identifying dimensions of personal strengths can elucidate the multidimensionality of the construct. We used a theory elaboration approach for the analysis, specifically to improve construct validation and provide clarity of the scope of each dimension of personal strength as evidenced by previously conducted empirical studies (19).

This systematic review was conducted in accordance with the Preferred Reporting Items for Systematic Reviews and MetaAnalyses (PRISMA) guidelines (20). First, we conducted a search of peer-reviewed literature to identify validated instruments that operationalized strength constructs. Second, we extracted information from the instrument about constructs, reliability, and validity. Finally, we grouped constructs into categories defined by the health assets framework to understand at what level personal strengths (eg, inner, personality, external) are measured by the instruments (9). Personal strengths can be innate or acquired. Health assets are influenced by antecedents (eg, values, beliefs), an individual's potential to pull from internal assets such as motivation, or external assets such as interpersonal support, to mobilize themselves to engage in positive health behaviors and improve their health (9).

\section{Data sources}

We conducted the literature search to include any articles published from the earliest articles in each database through July 1, 2019. We worked with a university librarian to implement a search of peer-reviewed articles that combined phrases to describe strengths and data collection instrument in PubMed, Web of Science, Cumulative Index of Nursing and Allied Health (CINAHL), PsycINFO, PsycTESTS, Social Work Abstracts, the Health and Psychosocial Instruments, and Embase. After limiting results to

The opinions expressed by authors contributing to this journal do not necessarily reflect the opinions of the U.S. Department of Health and Human Services, the Public Health Service, the Centers for Disease Control and Prevention, or the authors' affiliated institutions. 
humans and English-language articles and removing duplicates, the broad search was still explosive - returning more than 20,000 references. Therefore, we identified the strengths-related search terms with the worst specificity (ie, the largest absolute number of false positives based on a review of sampled abstracts for each term). The most problematic terms identified included "strength*", "health resource*", "protective factor*", and "resilience". Thereafter, we reviewed a randomly selected sample of 100 references and in working with the librarian, we replaced "strength*" in the main search with more specific terms capable of identifying appropriate references to balance a broad search with efficiency (ie, inner strength). Lastly, we reviewed any review papers (literature, scoping, systematic, meta-analysis) to further identify potentially relevant primary sources. Once we finalized our search strategy, we downloaded relevant citations to EndNoteX8 (Thomson ISI ResearchSoft), a reference management software. The search yielded 3,976 records.

\section{Criteria for study selection}

We were interested in instruments that assessed strengths; therefore, we identified studies that met the following criteria: 1) measured strengths at the individual, interpersonal, or environmental level; 2) applied the instrument to an adult population; 3) presented reliability or validity information; 4) used a structured, selfreported questionnaire to assess strengths; 5) had instruments that comprised 3 or more strength-related dimensions (ie, constructs); and 6) were peer-reviewed and published in English before July 2019. We also included instruments developed in languages other than English with findings written in English. We did not include studies focused on child and adolescent samples because strengths may manifest differently across the developmental period. We also excluded studies if they either measured strengths as a subscale of a larger instrument or used qualitative instruments (eg, semistructured interviews).

For screening we had 2 pairs of reviewers independently screen titles and abstracts. The full team met to resolve disagreements, reach consensus, and revisit the inclusion and exclusion criteria. If we could not reach consensus, the abstract was included for fulltext review. Full-text review comprised 3 teams of 2 who closely assessed studies against the inclusion and exclusion criteria, with a focus on reported reliability and validity information for strengths constructs.

\section{Data extraction}

We extracted descriptive characteristics, definitions of each construct, and reliability and validity information. For descriptive characteristics, we documented the purpose of the measure, the target population(s) in which the instrument was meant to be used (eg, gender-defined or clinically defined populations), and the settings in which the instrument was applied.

To assess reliability and validity information for each instrument we developed a structured extraction form by using the Scientific Advisory Committee of the Medical Outcome Trust (SACMOT) criteria (21). The 23 criteria are in 8 domains: conceptual models, reliability, validity, responsiveness, interpretability, burden, modes of administration, and cultural and language adaptations or translations (Table 1). Key validity criteria were face, content, criterionrelated and construct validity, and reliability measures. Validity studies for each instrument were reviewed, and 2 reviewers (D.D.W. and R.N.K.) independently extracted validity data for each instrument by using the SACMOT criteria. Results were compared and any inconsistencies were resolved through team discussion. The first author reviewed all extraction for quality assurance.

We created a table that included a row for every construct and the original definition from the source instrument to ensure fidelity throughout the extraction and synthesis process. Overlapping constructs were grouped together based on the similarity of their definitions. To organize the final table, we adapted the health assets framework developed by Rotegård and colleagues (9). Two authors (D.D.W. and R.N.K.) independently categorized each construct into the framework domains. Although the health assets framework distinguishes between assets (ie, strengths) and selfawareness, we considered self-awareness as a potential asset and coded constructs into this domain when appropriate. We developed emergent domains for constructs that did not fit into the existing framework. Finally, subdomains were created to reflect groups of constructs within domains. Unique constructs that were extracted from nonvalidated instruments were kept for the purposes of showcasing the diversity of strengths-related constructs and the gaps in validation.

\section{Results}

Beginning with 3,976 articles and after removing 1,807 duplicates, 2,169 articles remained (Figure). We excluded 2,057 articles during title and abstract review for not specifying a focus on strengths-related predictors or outcomes, not being published in English, or using a child or adolescent sample only. During the full-text review, we excluded an additional 86 non-English, non-peer reviewed, or not strength-relevant studies. This review yielded 20 studies that met our inclusion criteria and underwent

The opinions expressed by authors contributing to this journal do not necessarily reflect the opinions of the U.S. Department of Health and Human Services, the Public Health Service, the Centers for Disease Control and Prevention, or the authors' affiliated institutions. 
data extraction. Some studies had multiple strengths instruments, thereby producing 26 instruments for review. We extracted information about the populations in which these instruments were validated and sorted them (Table 2).

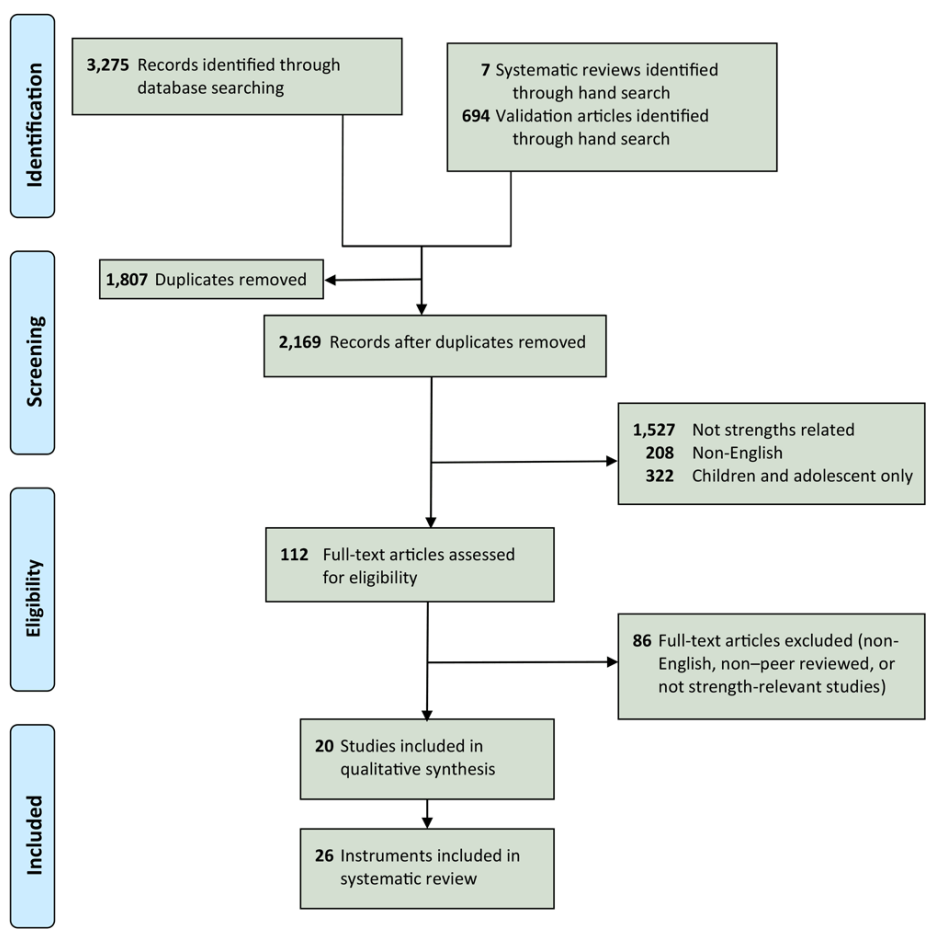

Figure. Preferred Reporting Items for Systematic Reviews and Meta-Analyses (PRISMA) flow diagram to obtain studies of strengths instruments to be analyzed for their relevance for chronic disease management.

Among the instruments assessed, 19 of 26 were developed in the United States, with the remaining 7 developed in Australia, Canada, Norway, Spain, Israel, the Netherlands, and the United Kingdom. Instruments were developed between 1957 and 2013. Although our method ensured all instruments were evaluated in at least 1 validity study, the number of validity studies ranged from 1 (eg, the Balanced Measure of Psychological Needs instrument [22]) to 55 (the California Psychological Inventory [23]), which is also the oldest instrument. Each instrument was validated for 1 or more populations (Table 2).

\section{Use in clinical populations}

Among the 26 instruments that matched our inclusion criteria, 5 focused on clinical settings. For example, the Cancer Empowerment Questionnaire measures strengths that cancer patients and survivors derive from themselves and their social network $(24,25)$. The Chronic Illness Resources Survey assesses support and resources at the individual, interpersonal, and community level (26).
The Inner Strength Questionnaire was constructed and validated among women with chronic illnesses in the United States (27). The Resilience Scale for Adults was constructed for outpatient adults in Norway (28). Although 5 instruments were developed specifically for clinic populations, an additional 7 instruments were developed in nonclinic settings but later validated in various clinic populations, including the Big Five Personality (29), Brief COPE (30,31), Connor-Davidson Resilience Scale (32), FiveFactor Personality Inventory (33), Interpersonal Support Evaluation List (34), Life Attitude Profile $(35,36)$, and Post-traumatic Growth Inventory $(37,38)$. The Caregiver Well-being Scale assesses family caregivers' strengths and domains where additional support is desirable for the caregiver (39).

\section{Scale construction, validity, and reliability assessment}

We used 18 SACMOT criteria (21) to examine scale construction, reliability, and validity. These 18 criteria were reliability, reliability data collection, reliability estimates, reliability coefficient calculations, methods for reproducibility, test-retest or inter-rater reliability, validity rationale, content-related validity, constructrelated validity, data on target population, hypothesis testing, criterion-related rationale, responsiveness, interpretability, respondent burden, administrative burden, administration modes, and cultural and language adaptations (Table 1). We found that the instruments with the most evidence of validity and reliability were the Big Five Personality (14 of 18 criteria), the California Psychological Inventory (13 of 18 criteria), the Resilience Scale for Adults (14 of 18 criteria), and the Sense of Coherence Scale (13 of 18 criteria) (40).

We found that definitions were clear for each construct, fulfilling the first SACMOT criterion (Table 1). All instruments had information on the dimensionality and distinctiveness of measured constructs. Most instruments (25 of 26) reported reliability estimates, such as a Cronbach $\alpha$ value (41).

Of the 26 instruments, 23 had at least 1 article detailing evidence on content validity, or the extent to which the items reflect the construct (42). Relatedly, construct validity measures comprised evidence for convergent and discriminant validity. We found 22 of 26 instruments assessed construct validity (eg, convergent and discriminant validity). Most instruments had measures of internal consistency to ensure reliability of the instrument and had reproducibility measures. Of the 26 instruments, 15 had information on less than $50 \%$ of the SACMOT criteria. The criterion with the least evidence was an evaluation of the administrative burden ( 2 of 26) and alternative modes of administering the instrument ( 3 of 26).

\footnotetext{
The opinions expressed by authors contributing to this journal do not necessarily reflect the opinions of the U.S. Department of Health and Human Services, the Public Health Service, the Centers for Disease Control and Prevention, or the authors' affiliated institutions.
} 


\section{Construct categorization}

We found 91 distinct constructs (Table 3). Most instruments contained unique constructs, indicating that constructs did not conceptually overlap with each other across instruments. Common constructs across instruments included flexibility, spiritual strength, and autonomy.

We organized the constructs into 3 domains based on the health assets framework developed by Rotegård et al (9): inner strengths, external strengths, and personality constructs. Approximately half of the constructs were coded as inner strengths $(n=49)$. On the basis of the framework, inner strengths comprised constructs that measure how people relate to others and their environment (relational, $\mathrm{n}=17$ ), what drives people when they encounter challenging situations (motivational, $\mathrm{n}=10$ ), characteristics that buffer individuals from undesired health outcomes (protective, $n=6$ ), self-determination to accomplish goals (volitional, $\mathrm{n}=9$ ), and selfreflective characteristics (self-awareness, $\mathrm{n}=7$ ).

Of 91 constructs, 13 were coded as external strengths, split into 2 domains: social resources and institutional support. Whereas social resources focus more on interpersonal resources, such as forms of tangible social support and aid $(n=7)$, institutional support contains constructs measuring community or institutionallevel characteristics that could support positive behaviors, such as the presence of community organizations $(n=6)$.

We classified 29 constructs as personality, which related to innate individual traits. Most of these personality constructs came from well-established personality-based instruments such as the Big Five Personality or Five-Factor Personality Inventory (33). Through coding, personality constructs were further split into 2 subdomains. One was resourcefulness $(n=10)$, defined as the ability to perform tasks independently or seek help from others when necessary. Constructs coded to resourcefulness included those pertaining to self-management skills and knowledge of and ability to use resources. The second subdomain was general personality traits $(n=19)$ related to intelligence, justice, approach to interaction with others, positivity, and approaches to learning.

\section{Discussion}

Personal strengths is a broad phenomenon comprising many constructs including internal strengths such as self-efficacy and personality or interpersonal strengths such as social support. Strengths can also come from community and social levels; however, we did not identify any validated scales focused on these higher-level strengths. The objective of this review was to identify and systematically summarize constructs that measure dimensions of personal strengths. This review shows evidence of a lim- ited number of reliable and valid instruments available to assess strengths for the adult population. We identified 26 instruments, most of which were developed in the United States and had reliability estimates. Content validity and construct validity were the most documented forms of validity, and information on administrative burden was the least documented. The instruments with the most reliability and validity evidence were personality assessments (Big Five Personality) and perceptions of interpersonal reactions (California Psychological Inventory) and resiliency (Sense of Coherence Scale).

Furthermore, 91 constructs are represented across the 26 instruments. Over 85 percent of constructs focused on inner strengths or personality factors rather than external resources (ie, community assets). Most of the constructs were focused on internal resources, reflecting the overarching health care rhetoric and practice of selfmanagement, which is focused on changing the individual without fully acknowledging the potential external assets that can be used to promote self-management behaviors $(43,44)$. These results are consistent with a review conducted by Golden and Earp (45), which found that $95 \%$ of behavioral interventions are conducted at the individual level and $67 \%$ are conducted at the interpersonal level. Despite evidence showing that community-level and policylevel factors are more effective than individual-level factors to change health behaviors, very few interventions are done at these levels (46). Overall, the rich set of constructs identified as inner strengths or personality factors can be leveraged to improve patients' health in primary care settings. Additional instruments focused on external assets can be developed to capture personal strengths and improve patient care more holistically.

The variability in validation studies may result from the high number of constructs used as proxies for personal strength; therefore, proper validity testing is necessary to advance the measurement of this broad construct. One specific type of validation that can help advance measurement is discriminant validity, which requires that measures of distinctly different constructs not be correlated with each other (42). Advancements in discriminating between the types of personal strengths can be made by further applying theory elaboration and construct proliferation techniques in future studies $(19,47)$.

In considering the use of personal strengths to inform the treatment and management of chronic conditions for individuals, studies have found evidence of cultivating personal strengths to improve self-management behaviors and improve patient health outcomes (48-50). However, we found that the number of instruments developed specifically for clinical populations or validated in clinical populations is limited. This may reflect how providers may focus on treating problems and identifying risk factors rather than evaluating patients on their personal strengths that can be in-

The opinions expressed by authors contributing to this journal do not necessarily reflect the opinions of the U.S. Department of Health and Human Services, the Public Health Service, the Centers for Disease Control and Prevention, or the authors' affiliated institutions. 
tegrated as part of the treatment plan. Therefore, additional studies are needed to develop instruments to measure personal strengths in clinical populations. Relatedly, interventions are needed in health care settings to integrate validated instruments and relevant items from those instruments in clinical care to identify personal strengths and to start conversations about strengthsbased approaches to improving chronic disease management. These interventions could target clinician awareness of instruments and knowledge of how to apply and interpret the results as a means of improving care.

\section{Limitations}

Our systematic review found that few instruments assess strengths at the community and societal levels to emphasize an ecological approach to strengths identification. Most instruments were not developed specifically for clinical populations, therefore additional testing is needed in these populations. We limited our inclusion criteria to adults but recognize that validity assessments are needed for children and adolescents if they are to be implemented in clinical settings, particularly in primary care settings. Although we examined instruments validated in adult populations, the studies described participants homogenously rather than examining adults by different stages of the life course (eg, older adults). Parsing out adults by these key developmental periods could be explored given that health care is sorted by age-specific specialties, such as geriatrics. In addition, quality of life instruments were not included in this search as these assess multiple domains of an individual's well-being. For this review, we wanted to limit the search to instruments that focus primarily on assessing personal strengths that an individual would have agency around, rather than instruments, such as health-related quality of life, that are broader constructs with a subdomain assessing strength. Our search may have been biased toward Western epistemologies, thereby excluding important strengths such as cultural group membership and connection, as research in Black psychology emphasizes (51).

\section{Future research}

Resilience, an important characteristic all on its own, was not included in our literature search because of how large the search results became. In addition, many of the instruments were validated in the general adult population or college students. Primary care settings need strengths-based instruments that account for developmental differences across adulthood (eg, younger or older adults) and that reflect how strengths are manifested in different cultural, racial, or ethnic groups (eg, Black, Indigenous, Asian, White). To ensure the validity of these measures in different populations, additional psychometric testing is needed to determine if each construct has the same meaning for each group. Implementation research is needed on how to use these instruments in health care settings in a way that supports the workflow of clinicians and leverages patient-generated information as part of the treatment process. Future research could use the constructs identified here to develop a comprehensive instrument of patient strengths in the clinical setting to improve chronic disease management. These instruments must be validated across multiple clinical populations, including those managing multiple chronic conditions such as cancer, hypertension, and type 2 diabetes.

We have reviewed 26 reliable and valid instruments that measure personal strengths in clinical and nonclinical adult populations. Constructs in these instruments can be used in both research and clinic settings to improve self-management behaviors among people with chronic conditions. Although these instruments tap into different forms of strengths, few instruments assess external strengths (eg, interpersonal, community). The development and validation of additional instruments to capture personal strengths is necessary to examine the multilevel influence of external strengths on individual behaviors and well-being.

\section{Acknowledgments}

We thank the Patient-Centered Outcomes Research Institute (PCORI) for their support of this review. We thank Emily Gillen, $\mathrm{PhD}$, for her help with reviewing articles, and thank University of North Carolina at Chapel Hill librarian Sarah Wright, MLIS, for her invaluable assistance in constructing the literature search.

The views presented in this manuscript are solely the responsibility of the authors and do not necessarily represent the views of PCORI, its Board of Governors, or Methodology Committee. PCORI is an independent, nonprofit organization authorized by the US Congress in 2010. Its mission is to fund research that will provide patients, their caregivers, and clinicians with the evidencebased information needed to make better-informed health care decisions. PCORI is committed to continually seeking input from a broad range of stakeholders to guide its work. Research reported in this manuscript was funded through a PCORI award (no. HSRP20142263).

D.D.W., R.N.K., and C.K. conducted the literature review and reviewed each article for inclusion with K.H.L. D.D.W., R.N.K., C.K., and K.H.L. collaboratively wrote the drafts of the manuscript. K.C.S. and A.M.W. provided extensive feedback and edits. All authors reviewed and edited the manuscript and approved the final version of the manuscript. The results have not been published or presented elsewhere. The authors have no conflicts of interest to declare. No financial disclosures were reported by the authors.

The opinions expressed by authors contributing to this journal do not necessarily reflect the opinions of the U.S. Department of Health and Human Services, the Public Health Service, the Centers for Disease Control and Prevention, or the authors' affiliated institutions. 


\section{Author Information}

Corresponding Author: Deshira D. Wallace, $\mathrm{PhD}$, Department of Health Behavior, University of North Carolina at Chapel Hill, 302 Rosenau Hall, 135 Dauer Dr, CB7440, Chapel Hill, NC 27599. Telephone: 984-464-0298. Email: ddwallac@live.unc.edu.

Author Affiliations: ${ }^{1}$ Gillings School of Global Public Health, University of North Carolina at Chapel Hill, Chapel Hill, North Carolina. ${ }^{2}$ Northern California Kaiser Permanente Division of Research, Oakland, California. ${ }^{3}$ University of Rochester Medical Center, Rochester, New York. ${ }^{4}$ Children's Institute, Rochester, New York. ${ }^{5}$ Center for Community Health Integration, Case Western Reserve University, Cleveland, Ohio.

\section{References}

1. Ward BW, Schiller JS, Goodman RA. Multiple chronic conditions among US adults: a 2012 update. Prev Chronic Dis 2014;11:E62.

2. Waters H, Graf M. The costs of chronic disease in the U.S. Santa Monica (CA): Milken Institute; 2018. 25 p. https:// milkeninstitute.org/reports/costs-chronic-disease-us. Accessed March 26, 2021.

3. Battersby M, Von Korff M, Schaefer J, Davis C, Ludman E, Greene SM, et al. Twelve evidence-based principles for implementing self-management support in primary care. Jt Comm J Qual Patient Saf 2010;36(12):561-70.

4. Bodenheimer T, Wagner EH, Grumbach K. Improving primary care for patients with chronic illness. JAMA 2002; 288(14):1775-9.

5. Bodenheimer T, Lorig K, Holman H, Grumbach K. Patient self-management of chronic disease in primary care. JAMA 2002;288(19):2469-75.

6. Wagner EH, Austin BT, Davis C, Hindmarsh M, Schaefer J, Bonomi A. Improving chronic illness care: translating evidence into action. Health Aff (Millwood) 2001; 20(6):64-78.

7. Bodenheimer T, Wagner EH, Grumbach K. Improving primary care for patients with chronic illness: the chronic care model, part 2. JAMA 2002;288(15):1909-14.

8. Staudt M, Howard MO, Drake B. The operationalization, implementation, and effectiveness of the strengths perspective. J Soc Serv Res 2001;27(3):1-21.

9. Rotegård AK, Moore SM, Fagermoen MS, Ruland CM. Health assets: a concept analysis. Int J Nurs Stud 2010;47(4):513-25.

10. Simmons CA, Lehmann P. Strengths and psychotherapy. Tools for strength based assessment and evaluation. New York (NY): Springer Publishing Company; 2013. p. 1-17.
11. Flückiger C, Caspar F, Holtforth MG, Willutzki U. Working with patients' strengths: a microprocess approach. Psychother Res 2009;19(2):213-23.

12. Kress VE, Hoffman RM. Empowering adolescent survivors of sexual abuse: application of a solution-focused Ericksonian Counseling Group. J Humanist Educ Dev 2008;47(2):172-86.

13. Skolasky RL, Mackenzie EJ, Wegener ST, Riley LH 3d. Patient activation and functional recovery in persons undergoing spine surgery. J Bone Joint Surg Am 2011; 93(18):1665-71.

14. Bird VJ, Le Boutillier C, Leamy M, Larsen J, Oades LG, Williams J, et al. Assessing the strengths of mental health consumers: a systematic review. Psychol Assess 2012; 24(4):1024-33.

15. Graybeal C. Strengths-based social work assessment: transforming the dominant paradigm. Fam Soc 2001; 82(3):233-42.

16. Rashid T, Ostermann RF. Strength-based assessment in clinical practice. J Clin Psychol 2009;65(5):488-98.

17. Tedeschi RG, Kilmer RP. Assessing strengths, resilience, and growth to guide clinical interventions. Prof Psychol Res Pr 2005;36(3):230-7.

18. Kristjansdottir OB, Stenberg U, Mirkovic J, Krogseth T, Ljoså TM, Stange KC, et al. Personal strengths reported by people with chronic illness: a qualitative study. Health Expect 2018; 21(4):787-95.

19. Fisher G, Aguinis H. Using theory elaboration to make theoretical advancements. Organ Res Methods 2017; 20(3):438-64.

20. Moher D, Liberati A, Tetzlaff J, Altman DG; PRISMA Group. Preferred reporting items for systematic reviews and metaanalyses: the PRISMA statement. Ann Intern Med 2009; 151(4):264-9, W64.

21. Aaronson N, Alonso J, Burnam A, Lohr KN, Patrick DL, Perrin E, et al. Assessing health status and quality-of-life instruments: attributes and review criteria. Qual Life Res 2002; 11(3):193-205.

22. Sheldon KM, Hilpert JC. The balanced measure of psychological needs (BMPN) scale: an alternative domain general measure of need satisfaction. Motiv Emot 2012; 36(4):439-51.

23. Dicken CF. Convergent and discriminant validity of the California Psychological Inventory. Educ Psychol Meas 1963; 23(3):449-59.

24. van den Berg SW, van Amstel FK, Ottevanger PB, Gielissen MF, Prins JB. The Cancer Empowerment Questionnaire: psychological empowerment in breast cancer survivors. J Psychosoc Oncol 2013;31(5):565-83.

The opinions expressed by authors contributing to this journal do not necessarily reflect the opinions of the U.S. Department of Health and Human Services, the Public Health Service, the Centers for Disease Control and Prevention, or the authors' affiliated institutions. 
25. Custers JA, van den Berg SW, van Laarhoven HW, Bleiker EM, Gielissen MF, Prins JB. The Cancer Worry Scale: detecting fear of recurrence in breast cancer survivors. Cancer Nurs 2014;37(1):E44-50.

26. Glasgow RE, Strycker LA, Toobert DJ, Eakin E. A socialecologic approach to assessing support for disease selfmanagement: the Chronic Illness Resources Survey. J Behav Med 2000;23(6):559-83.

27. Roux G, Lewis K, Younger J, Dingley C. Development and testing of the inner strength questionnaire. J Cult Divers 2003; 10(1):4-5.

28. Friborg O, Hjemdal O, Rosenvinge JH, Martinussen M. A new rating scale for adult resilience: what are the central protective resources behind healthy adjustment? Int J Methods Psychiatr Res 2003;12(2):65-76.

29. Fan J, Zhu X-z, Tang L-1, Wang Y-p, Li L, Yang Y, et al. Reliability and validity of Chinese Big Five Personality inventory brief version in breast cancer women. Chinese Journal of Clinical Psychology 2013;21(5):783-5.

30. Snell DL, Siegert RJ, Hay-Smith EJ, Surgenor LJ. Factor structure of the Brief COPE in people with mild traumatic brain injury. J Head Trauma Rehabil 2011;26(6):468-77.

31. Mejorada RE, Tufiño MA, Sierra AV, Guerrero OT, Rosas AR, Sánchez Sosa JJ. Afrontamiento en pacientes con cáncer de mama en radioterapia: Análisis de la Escala COPE Breve. Psicología y Salud 2013;23(1):55-62. Spanish.

32. Connor KM, Davidson JR. Development of a new resilience scale: the Connor-Davidson Resilience Scale (CD-RISC). Depress Anxiety 2003;18(2):76-82.

33. H of s e e W. B ig-Five-profie le n van persoonlijkheidsstoornissen. Psychodiagnostisch gereedschap. $=$ The Big Five profile of personality disorders: psychodiagnostic tools. Psychooncology 1999;34(9):381-4.

34. Bastardo YM, Kimberlin CL. Relationship between quality of life, social support and disease-related factors in HIV-infected persons in Venezuela. AIDS Care 2000;12(5):673-84.

35. Ahern NR, Kiehl EM, Sole ML, Byers J. A review of instruments measuring resilience. Issues Compr Pediatr Nurs 2006;29(2):103-25.

36. Anagnostopoulos F, Slater J, Fitzsimmons D, Kolokotroni P. Exploring global meaning in Greek breast cancer patients: validation of the Life Attitude Profile - Revised (LAP-R). Psychooncology 2011;20(4):419-27.

37. Mack J, Herrberg M, Hetzel A, Wallesch CW, Bengel J, Schulz M, et al. The factorial and discriminant validity of the German version of the Post-traumatic Growth Inventory in stroke patients. Neuropsychol Rehabil 2015;25(2):216-32.

38. Mystakidou K, Tsilika E, Parpa E, Galanos A, Vlahos L. Posttraumatic growth in advanced cancer patients receiving palliative care. Br J Health Psychol 2008;13(Pt 4):633-46.
39. Tebb S. An aid to empowerment: a caregiver well-being scale. Health Soc Work 1995;20(2):87-92.

40. Frenz AW, Carey MP, Jorgensen RS. Psychometric evaluation of Antonovsky's Sense of Coherence Scale. Psychol Assess 1993;5(2):145-53.

41. Alwin DF. Measurement errors in cross-cultural surveys. Extracted from Margins of error - a study of reliability in survey measurement. New York (NY): John Wiley and Sons; 2007.

42. DeVellis RF. Scale development: theory and applications. Thousand Oaks (CA): Sage Publications; 2016.

43. Madden MH, Tomsik P, Terchek J, Navracruz L, Reichsman A, Clark TC, et al. Keys to successful diabetes selfmanagement for uninsured patients: social support, observational learning, and turning points: a safety net providers' strategic alliance study. J Natl Med Assoc 2011; 103(3):257-64.

44. Reichsman A, Werner J, Cella P, Bobiak S, Stange KC; SNPSA Diabetes Study Working Group. Opportunities for improved diabetes care among patients of safety net practices: a safety net providers' strategic alliance study. J Natl Med Assoc 2009;101(1):4-11.

45. Golden SD, Earp JAL. Social ecological approaches to individuals and their contexts: twenty years of Health Education \& Behavior health promotion interventions. Health Educ Behav 2012;39(3):364-72.

46. Hirsch G, Homer J, Trogdon J, Wile K, Orenstein D. Using simulation to compare 4 categories of intervention for reducing cardiovascular disease risks. Am J Public Health 2014; 104(7):1187-95.

47. Shaffer JA, DeGeest D, Li A. Tackling the problem of construct proliferation: a guide to assessing the discriminant validity of conceptually related constructs. Organ Res Methods 2016;19(1):80-110.

48. Tai-Seale M, Downing NL, Jones VG, Milani RV, Zhao B, Clay B, et al. Technology-enabled consumer engagement: promising practices at four health care delivery organizations. Health Aff (Millwood) 2019;38(3):383-90.

49. Greene J, Hibbard JH, Sacks R, Overton V, Parrotta CD. When patient activation levels change, health outcomes and costs change, too. Health Aff (Millwood) 2015;34(3):431-7.

50. Alegría M, Sribney W, Perez D, Laderman M, Keefe K. The role of patient activation on patient-provider communication and quality of care for US and foreign born Latino patients. J Gen Intern Med 2009;24(Suppl 3):534-41.

51. Jamison D. The SAGE encyclopedia of African cultural heritage in North America. Thousand Oaks (CA): Sage Publications; 2015.

The opinions expressed by authors contributing to this journal do not necessarily reflect the opinions of the U.S. Department of Health and Human Services, the Public Health Service, the Centers for Disease Control and Prevention, or the authors' affiliated institutions. 


\section{Tables}

Table 1. Criteria and Attributes for Reviewing Patient Strengths Instruments $(N=26)^{a}$

\begin{tabular}{|c|c|c|c|}
\hline Attribute & Description & Review Criteria & $\begin{array}{l}\text { No. of Instruments } \\
\text { That Fit Criteria }\end{array}$ \\
\hline \multirow{4}{*}{$\begin{array}{l}\text { Conceptual and } \\
\text { measurement model }\end{array}$} & \multirow{4}{*}{$\begin{array}{l}\text { The rationale for and description of the } \\
\text { concept and the populations that a } \\
\text { measure is intended to assess and the } \\
\text { relationship between these concepts }\end{array}$} & Rationale for and description of the concept to be measured & 26 \\
\hline & & Target population involvement in content derivation & 8 \\
\hline & & Information on dimensionality and distinctiveness of scales & 26 \\
\hline & & Rationale for deriving scale scores & 7 \\
\hline Reliability & \multicolumn{2}{|c|}{ The degree to which an instrument is free from random error } & 5 \\
\hline \multirow[t]{3}{*}{ Internal consistency } & \multirow{3}{*}{$\begin{array}{l}\text { The precision of a scale, based on the } \\
\text { homogeneity (intercorrelations) of the } \\
\text { scale's items at one point in time }\end{array}$} & Methods to collect reliability data & 22 \\
\hline & & $\begin{array}{l}\text { Reliability estimates and standard errors for all score elements } \\
\text { (classical test) or standard error of the mean over the range of } \\
\text { scale and marginal reliability of each scale (modern Item } \\
\text { Response Theory) }\end{array}$ & 25 \\
\hline & & $\begin{array}{l}\text { Data to calculate reliability coefficients or actual calculations of } \\
\text { reliability coefficients }\end{array}$ & 21 \\
\hline \multirow[t]{2}{*}{ Reproducibility } & \multirow{2}{*}{$\begin{array}{l}\text { Stability of an instrument over time } \\
\text { (test-retest) and inter-rater agreement at } \\
\text { one point in time }\end{array}$} & Methods employed to collect reproducibility data & 16 \\
\hline & & $\begin{array}{l}\text { Information on test-retest reliability and inter-rater reliability } \\
\text { based on intraclass correlation coefficients }\end{array}$ & 19 \\
\hline Validity & $\begin{array}{l}\text { The degree to which the instrument } \\
\text { measures what it purports to measure }\end{array}$ & $\begin{array}{l}\text { Rationale supporting the particular mix of evidence presented for } \\
\text { the intended uses }\end{array}$ & 8 \\
\hline Content-related & $\begin{array}{l}\text { Evidence that the domain of an } \\
\text { instrument is appropriate relative to its } \\
\text { intended use }\end{array}$ & Clear description of the methods employed to collect validity data & 23 \\
\hline Construct-related & $\begin{array}{l}\text { Evidence that supports a proposed } \\
\text { interpretation of scores based on } \\
\text { theoretical implications associated with } \\
\text { the constructs being measured }\end{array}$ & $\begin{array}{l}\text { - Composition of the sample used to examine validity (in detail) } \\
\text { - Entails convergent validity, which measures whether } 2 \\
\text { constructs that are theoretically related are actually related } \\
\text { - Discriminant validity measures if } 2 \text { constructs that should not } \\
\text { be related are actually observed not to be related }\end{array}$ & 22 \\
\hline \multirow[t]{3}{*}{ Criterion-related } & \multirow{3}{*}{$\begin{array}{l}\text { Evidence that shows the extent to which } \\
\text { scores of the instrument are related to a } \\
\text { criterion measure }\end{array}$} & $\begin{array}{l}\text { Criterion measures data specified for each major population of } \\
\text { interest }\end{array}$ & 14 \\
\hline & & Hypotheses tested and data relating to the tests & 8 \\
\hline & & Clear rationale and support for the choice of criteria measures & 11 \\
\hline Responsiveness & $\begin{array}{l}\text { An instrument's ability to detect change } \\
\text { over time }\end{array}$ & $\begin{array}{l}\text { Longitudinal data that compare a group that is expected to } \\
\text { change with a group that is expected to remain stable }\end{array}$ & 7 \\
\hline Interpretability & $\begin{array}{l}\text { The degree to which one can assign easily } \\
\text { understood meaning to an instrument's } \\
\text { quantitative scores }\end{array}$ & $\begin{array}{l}\text { Rationale for selection of external criteria of populations for } \\
\text { purposes of comparison and interpretability of data }\end{array}$ & 5 \\
\hline Burden & \multicolumn{2}{|c|}{ The time, effort, and other demands of the instrument } & 0 \\
\hline Respondent burden & $\begin{array}{l}\text { The time, effort, and other demands } \\
\text { placed on those to whom the instrument } \\
\text { is administered }\end{array}$ & $\begin{array}{l}\text { Information on 1) average and range of the time needed to } \\
\text { complete the instrument, 2) reading and comprehension level, } \\
\text { and 3) any special requirements or requests made of respondent }\end{array}$ & 5 \\
\hline Administrative burden & $\begin{array}{l}\text { The time, effort, and other demands } \\
\text { placed on those who administer the } \\
\text { instrument }\end{array}$ & $\begin{array}{l}\text { Information about any resources required for administration of } \\
\text { the instrument }\end{array}$ & 2 \\
\hline Modes of administration & These include self-report, interviewer- & Information on the comparability of alternative modes & 3 \\
\hline
\end{tabular}

${ }^{a}$ Shortened version of key criteria based on Aaronson et al (21). 
(continued)

Table 1. Criteria and Attributes for Reviewing Patient Strengths Instruments $(\mathrm{N}=26)^{a}$

\begin{tabular}{|l|l|l|l|}
\hline Attribute & \multicolumn{1}{|c|}{ Description } & \multicolumn{1}{|c|}{$\begin{array}{c}\text { Review Criteria } \\
\text { That Fit Criteria }\end{array}$} \\
\hline & $\begin{array}{l}\text { administered, trained observer rating, } \\
\text { computer-assisted interviewer- } \\
\text { administered, performance-based } \\
\text { measures }\end{array}$ & \\
\hline $\begin{array}{l}\text { Cultural and language } \\
\text { adaptations or translations }\end{array}$ & $\begin{array}{l}\text { Involves 2 primary steps: 1) assessment } \\
\text { of conceptual and linguistic equivalence, } \\
\text { and 2) evaluation of measurement } \\
\text { properties }\end{array}$ & $\begin{array}{l}\text { Any significant differences between the original and translated } \\
\text { versions }\end{array}$ & 11 \\
\hline
\end{tabular}

${ }^{\text {a }}$ Shortened version of key criteria based on Aaronson et al (21). 
Table 2. Description of Assessments of Patient Strengths Instruments ${ }^{a}$

\begin{tabular}{|c|c|c|c|c|}
\hline $\begin{array}{l}\text { No. and } \\
\text { Assessment Name }\end{array}$ & Description & Populations Scale Was Applied & $\begin{array}{l}\text { No. of Validity } \\
\text { Articles }\end{array}$ & $\begin{array}{l}\text { Year and Place } \\
\text { Developed }\end{array}$ \\
\hline $\begin{array}{l}\text { Balanced Measure } \\
\text { of Psychological } \\
\text { Needs }\end{array}$ & $\begin{array}{l}\text { Measures autonomy, } \\
\text { competence, and relatedness. }\end{array}$ & College students in United States (Sheldon 2012) & 1 & $\begin{array}{l}\text { 2012, United } \\
\text { States }\end{array}$ \\
\hline $\begin{array}{l}\text { Baruth Protective } \\
\text { Factors Inventory }\end{array}$ & Measures resiliency. & Adults (Baruth 2002) & 1 & $\begin{array}{l}\text { 2001, United } \\
\text { States }\end{array}$ \\
\hline Big Five Personality & $\begin{array}{l}\text { The Big Five Personality traits } \\
\text { are extraversion, agreeableness, } \\
\text { conscientiousness, emotional } \\
\text { stability, and openness to } \\
\text { experience, with each of these } \\
\text { being measured on a } \\
\text { continuum. }\end{array}$ & $\begin{array}{l}5 \text { major occupational groupings: professionals, police, managers, sales, } \\
\text { skilled/semi-skilled (Barrick 1991); Hispanic bilingual college students in } \\
\text { Spain and United States (Benet-Martínez 1998); Italian adults (Fossati } \\
\text { 2011); Dutch adults (Smits 2011) (Van Heck 1994); Estonian and } \\
\text { Finnish adults (Pulver 1995); Polish adults (Strelau 1995); Japanese } \\
\text { adults (Wada 1996); Kuwaiti adults (El-Ansarey 1997); college students } \\
\text { in Brazil (Nunes 2007) (Hauck Filho 2012); German adults (Rammstedt } \\
\text { 2007); Croatian adults (Mlacić 2008) (Hrebíčková 2010); Turkish adults } \\
\text { (Karaman 2010) (Gençöz 2012) (Morsünbül 2014); Chinese college } \\
\text { students (Huang 2010) (Wang 2010) (Shi 2015); Argentine adults } \\
\text { (Ledesma 2011); Chinese female patients with breast cancer (Fan } \\
\text { 2013) }\end{array}$ & 38 & $\begin{array}{l}\text { 1961, United } \\
\text { States }\end{array}$ \\
\hline Brief COPE & $\begin{array}{l}\text { Measures coping with life } \\
\text { stresses associated with a } \\
\text { specific activity. Contains } 3 \\
\text { subscales, with } 2 \text { of the } 3 \\
\text { positively framed. }\end{array}$ & $\begin{array}{l}\text { Nonstudent adult sample in United States (Carver 1997); French college } \\
\text { students (Muller 2003) (Doron 2014); Swedish college students } \\
\text { (Muhonen 2005); medical students in Malaysia (Yusoff 2010); } \\
\text { caregivers of HIV-positive patients in Kenya (Kimemia 2011); adults with } \\
\text { mild traumatic brain injury in US (Snell 2011); women with breast cancer } \\
\text { in Mexico (Mejorada 2013); persons living with HIV/AIDS in southern } \\
\text { India (Mohanraj 2015); people living with HIV/AIDS in China (Su 2015) }\end{array}$ & 10 & $\begin{array}{l}\text { 1989, United } \\
\text { States }\end{array}$ \\
\hline $\begin{array}{l}\text { California } \\
\text { Psychological } \\
\text { Inventory }\end{array}$ & $\begin{array}{l}\text { Measures personality and } \\
\text { behavior under } 4 \text { domains: } \\
\text { interpersonal style, intrapersonal } \\
\text { style, achievement style, and } \\
\text { stylistic modes. }\end{array}$ & $\begin{array}{l}\text { College students in United States (Gough 1953) (Dicken 1963) (Darbes } \\
\text { 1964); managers and supervisors in United States (Goodstein 1963) } \\
\text { (Gough 1984); US Navy (Knapp 1963); Indian college students (Gough } \\
\text { 1964); adults in France, Italy, Venezuela, and Turkey (Gough 1966); } \\
\text { French adults (Chapuis 1970); Japanese college students (Nishiyama } \\
\text { 1973) (Nishiyama 1975); Swedish delinquent and nondelinquent adults } \\
\text { (Rosen 1974); multicountry delinquent and nondelinquent adults (Gough } \\
\text { 1974); Israeli adults (Cohen 1977); Romanian adults (Pitariu 1980) } \\
\text { (Pitariu 1981); Pakistani college students (Ahmed 1986); adults in } \\
\text { Kuwait and Egypt (Torki 1988); Taiwanese adults (Ying 1991); US Coast } \\
\text { Guard (Blake 1993); white-collar crime inmates in United States (Collins } \\
\text { 1993); adults with alcoholism in United States (Kadden 1996); } \\
\text { Norwegian college students (Sandal 2002) }\end{array}$ & 55 & $\begin{array}{l}\text { 1957, United } \\
\text { States }\end{array}$ \\
\hline $\begin{array}{l}\text { Cancer } \\
\text { Empowerment } \\
\text { Questionnaire }\end{array}$ & $\begin{array}{l}\text { Contains } 6 \text { factors; used to } \\
\text { measure strengths that patients } \\
\text { derive from themselves and } \\
\text { their network: health care, social } \\
\text { support, self-esteem, feeling } \\
\text { connected, self-management, } \\
\text { and community support. }\end{array}$ & $\begin{array}{l}\text { Females with breast cancer in Korea (Shin 2015); female breast cancer } \\
\text { survivors in Netherlands (van den Berg 2013) (Custers 2014) }\end{array}$ & 3 & $\begin{array}{l}\text { 2013, } \\
\text { Netherlands }\end{array}$ \\
\hline $\begin{array}{l}\text { Caregiver Well- } \\
\text { Being Scale }\end{array}$ & $\begin{array}{l}\text { Two subscales: 1) basic needs } \\
\text { subscale ( } 4 \text { factors: expression } \\
\text { of feelings, attendance to } \\
\text { physical needs, self-esteem, and } \\
\text { security), and } 2 \text { ) activities of } \\
\text { living ( } 5 \text { factors: time for self, } \\
\text { maintenance of functions } \\
\text { outside the home, family } \\
\text { support, household } \\
\text { maintenance, household tasks). }\end{array}$ & $\begin{array}{l}\text { Medical informal caregivers in United States, mostly women (Tebb 1995) } \\
\text { (Rubio 1999) (Berg-Weger 2000) (Rubio 2003) (Tebb 2013); social } \\
\text { workers in United States (Rubio 2003); medical informal caregivers in } \\
\text { Turkey (Demirtepe 2009) }\end{array}$ & 6 & $\begin{array}{l}\text { 1995, United } \\
\text { States }\end{array}$ \\
\hline $\begin{array}{l}\text { Chronic Illness } \\
\text { Resources Survey }\end{array}$ & $\begin{array}{l}\text { Measures support and } \\
\text { resources at each of the levels } \\
\text { of the socioecological } \\
\text { framework. }\end{array}$ & $\begin{array}{l}\text { Patients with chronic conditions (Glasgow 2000), Spanish-speaking } \\
\text { population (Eakin 2007) }\end{array}$ & 3 & $\begin{array}{l}\text { 2000, United } \\
\text { States }\end{array}$ \\
\hline
\end{tabular}

\footnotetext{
${ }^{\mathrm{a}} \mathrm{A}$ list of the publications cited in this table is in the Appendix.
} 
(continued)

Table 2. Description of Assessments of Patient Strengths Instruments ${ }^{a}$

\begin{tabular}{|c|c|c|c|c|}
\hline $\begin{array}{l}\text { No. and } \\
\text { Assessment Name }\end{array}$ & Description & Populations Scale Was Applied & $\begin{array}{l}\text { No. of Validity } \\
\text { Articles }\end{array}$ & $\begin{array}{l}\text { Year and Place } \\
\text { Developed }\end{array}$ \\
\hline $\begin{array}{l}\text { College Student } \\
\text { Hardiness Measure }\end{array}$ & $\begin{array}{l}\text { Measures } 3 \text { factors of hardiness: } \\
\text { control, commitment, and } \\
\text { challenge. }\end{array}$ & Indian American college students (Atri 2007) & 1 & $\begin{array}{l}\text { 2007, United } \\
\text { States }\end{array}$ \\
\hline $\begin{array}{l}\text { Connor-Davidson } \\
\text { Resilience Scale }\end{array}$ & $\begin{array}{l}\text { Developed to measure coping } \\
\text { ability. }\end{array}$ & $\begin{array}{l}\text { General population, primary care outpatient, psychiatric care outpatient } \\
\text { in United States (Connor 2003); Korean adults (college students, nurses, } \\
\text { firefighters) (Baek 2010); Spanish-speaking patients with fibromylagia } \\
\text { (Notario-Pacheco 2014); Korean firefighters and rescue workers (Jeong } \\
\text { 2015); German adults (Sarubin 2015); General Hong Kong population } \\
\text { (Ni 2016); Chinese military (Xie 2016) }\end{array}$ & 8 & $\begin{array}{l}\text { 2003, United } \\
\text { States }\end{array}$ \\
\hline $\begin{array}{l}\text { Dispositional } \\
\text { Resilience Scale }\end{array}$ & $\begin{array}{l}\text { Measures hardiness and } \\
\text { includes dimensions of control, } \\
\text { commitment, and challenge. }\end{array}$ & $\begin{array}{l}\text { Norwegian armed forces employees (Hystad 2010); Italian adults } \\
\text { (Picardi 2012); adults (Bartone 1989) }\end{array}$ & $\begin{array}{c}4 \text { (plus } 2 \\
\text { unpublished) }\end{array}$ & $\begin{array}{l}\text { 1989, United } \\
\text { States }\end{array}$ \\
\hline $\begin{array}{l}\text { Five-Factor } \\
\text { Personality } \\
\text { Inventory }\end{array}$ & $\begin{array}{l}\text { Assessed the Big Five factors of } \\
\text { personality: extraversion, } \\
\text { agreeableness, } \\
\text { conscientiousness, emotional } \\
\text { stability, and autonomy. }\end{array}$ & $\begin{array}{l}\text { College students, faculty in United States (Hendriks 1999); internet } \\
\text { users (Buchannan 2005); adults in Italy (Perugini 1998); male military } \\
\text { recruits (Marshall 1994); Spanish adults (Salgudo 1997) (Rodríguez } \\
\text { 2001); Dutch adults with personality disorders (Hendriks 1999); Turkish } \\
\text { adults (Somer 2002) (Araz 2014); various European adult populations } \\
\text { (De Fruyt 2004) (Sharma 2009); Indian adults (Sharma 2009) }\end{array}$ & 13 & $\begin{array}{l}\text { 1991, United } \\
\text { States }\end{array}$ \\
\hline $\begin{array}{l}\text { Inner Strength } \\
\text { Questionnaire }\end{array}$ & $\begin{array}{l}\text { Developed to measure } 4 \\
\text { dimensions for inner strength: } \\
\text { knowing and searching, } \\
\text { connectedness, physical self- } \\
\text { spirit, and mental self-spirit. }\end{array}$ & Women with chronic illness in United States (Roux 2003) (Lewis 2011) & 2 & $\begin{array}{l}\text { 2003, United } \\
\text { States }\end{array}$ \\
\hline $\begin{array}{l}\text { Interpersonal } \\
\text { Support Evaluation } \\
\text { List }\end{array}$ & $\begin{array}{l}\text { Used to measure } 4 \text { conceptually } \\
\text { distinct dimensions proposed to } \\
\text { buffer the effects of stressful } \\
\text { events: appraisal support, } \\
\text { tangible assets support, } \\
\text { belonging support, and self- } \\
\text { esteem support. }\end{array}$ & $\begin{array}{l}\text { College students (Brookings 1988) (Schonfeld 1991); homeless adults } \\
\text { (Bates 1995) (Bates 1999); spinal cord-injured adults (McColl 1995) } \\
\text { (Rintala 2013); HIV-infected adults in Venezuela (Bastardo 2000); Greek } \\
\text { college students (Delistamati 2006); Polish adults (Szlachta 2009); } \\
\text { battered women (Baumann 2012); Spanish-speaking college students } \\
\text { (Mendoza 2012); Italian adults (Moretti 2012); Hispanic/Latino adults in } \\
\text { United States (Merz 2014); adults by race (Sacco 2011) }\end{array}$ & 14 & $\begin{array}{l}\text { 1985, United } \\
\text { States }\end{array}$ \\
\hline Life Attitude Profile & $\begin{array}{l}\text { Measures an individual's } \\
\text { attitude toward life and how they } \\
\text { find meaning and purpose. }\end{array}$ & $\begin{array}{l}\text { Canadian undergraduates (Reker 1981), Greek breast cancer patients } \\
\text { (Anagnostopoulos 2011) }\end{array}$ & 5 & $\begin{array}{l}\text { 1981, Ontario, } \\
\text { Canada }\end{array}$ \\
\hline $\begin{array}{l}\text { Mental Toughness } \\
\text { Questionnaire } \\
\text { (MTQ48) }\end{array}$ & $\begin{array}{l}\text { The MTQ48 assesses total } \\
\text { mental toughness and } 4 \\
\text { subcomponents: challenge, } \\
\text { commitment, confidence, and } \\
\text { control. Translated into } 14 \\
\text { languages. Used in occupational } \\
\text { sector, education, health, and } \\
\text { sports. }\end{array}$ & $\begin{array}{l}\text { Adult athletes (Clough 2008) (Gucciardi 2012); university athletes } \\
\text { (Sheard 2009); office management and administrative workers } \\
\text { (Gucciardi 2012) (Perry 2013); general adult men (Perry 2013) }\end{array}$ & 6 & $\begin{array}{l}\text { 2002, United } \\
\text { Kingdom }\end{array}$ \\
\hline $\begin{array}{l}\text { Norbeck Social } \\
\text { Support } \\
\text { Questionnaire }\end{array}$ & Measures social support. & $\begin{array}{l}\text { Adults (graduate students in nursing) (Norbeck 1981); Spanish speakers } \\
\text { (LaRoche 1994) }\end{array}$ & 4 & $\begin{array}{l}\text { 1980, United } \\
\text { States }\end{array}$ \\
\hline $\begin{array}{l}\text { Post Traumatic } \\
\text { Growth Inventory }\end{array}$ & $\begin{array}{l}\text { Measures the general tendency } \\
\text { to experience difficult events in } \\
\text { a way that produces perceptions } \\
\text { of benefits. }\end{array}$ & $\begin{array}{l}\text { Undergraduate students with significant traumatic event in the past } 5 \\
\text { years (Tedeschi 1996); cancer patients receiving palliative care } \\
\text { (Mystakidou 2008); South American earthquake survivors (Leiva 2015); } \\
\text { German adult stroke patients (Mack 2015); adult men who report sexual } \\
\text { abuse during childhood (Saltzman 2015) }\end{array}$ & 13 & $\begin{array}{l}\text { 1996, United } \\
\text { States }\end{array}$ \\
\hline $\begin{array}{l}\text { Psychological } \\
\text { Capital } \\
\text { Questionnaire } \\
\end{array}$ & $\begin{array}{l}\text { Measures hope, optimism, self- } \\
\text { efficacy, and resilience. }\end{array}$ & $\begin{array}{l}\text { Validated in the adult population in the United States and South Africa } \\
\text { (Avey 2009); management students and engineers/technicians in the } \\
\text { United States (Luthans 2009); Chinese workers (Wang 2012) }\end{array}$ & 7 & $\begin{array}{l}\text { 2004, United } \\
\text { States }\end{array}$ \\
\hline $\begin{array}{l}\text { Psychological Well- } \\
\text { being Questionnaire }\end{array}$ & $\begin{array}{l}\text { Assesses individual's well-being } \\
\text { at a particular moment in time } \\
\text { within } 6 \text { dimensions: autonomy, } \\
\text { environmental mastery, personal }\end{array}$ & Adult population aged 18 or older (Ryff 1995) & 2 & $\begin{array}{l}\text { 1989, United } \\
\text { States }\end{array}$ \\
\hline
\end{tabular}

${ }^{a}$ A list of the publications cited in this table is in the Appendix. 
(continued)

Table 2. Description of Assessments of Patient Strengths Instruments ${ }^{a}$

\begin{tabular}{|c|c|c|c|c|}
\hline $\begin{array}{l}\text { No. and } \\
\text { Assessment Name }\end{array}$ & Description & Populations Scale Was Applied & $\begin{array}{l}\text { No. of Validity } \\
\text { Articles }\end{array}$ & $\begin{array}{l}\text { Year and Place } \\
\text { Developed }\end{array}$ \\
\hline & $\begin{array}{l}\text { growth, positive relationships } \\
\text { with others, purpose in life, and } \\
\text { self-acceptance. }\end{array}$ & & & \\
\hline $\begin{array}{l}\text { Resilience Scale for } \\
\text { Adults }\end{array}$ & $\begin{array}{l}\text { Measures } 5 \text { resilience factors } \\
\text { among adults: personal } \\
\text { strength, social competence, } \\
\text { structured style, family cohesion, } \\
\text { and social resources. }\end{array}$ & $\begin{array}{l}\text { Adult outpatient clinic patients in Norway (Friborg 2003); military college } \\
\text { students in Norway (Friborg 2005); university students in Norway } \\
\text { (Friborg 2006); university students in Iran (Jowkar 2010); French- } \\
\text { speaking Belgian college students (Hjemdal 2011); clinical and } \\
\text { nonclinical college patients/students (Hilbig 2015); adults in Brazil } \\
\text { (Hjemdal 2015) }\end{array}$ & 7 & 2003, Norway \\
\hline $\begin{array}{l}\text { Resistance to } \\
\text { Trauma Test }\end{array}$ & $\begin{array}{l}\text { Measures } 6 \text { factors of personal } \\
\text { strengths or resources: } \\
\text { emotional intelligence and } \\
\text { internal control; values, } \\
\text { principles, and ethics; optimism, } \\
\text { hope, and sense of humor; } \\
\text { social skills and relationships; } \\
\text { acceptance and adaptation; and } \\
\text { internal congruency. }\end{array}$ & $\begin{array}{l}\text { Spanish population who had experienced a traumatic event (Urra Portillo } \\
\text { 2014) }\end{array}$ & 1 & 2012, Spain \\
\hline $\begin{array}{l}\text { Response to } \\
\text { Stressful } \\
\text { Experiences Scale }\end{array}$ & $\begin{array}{l}5 \text { protective factors: meaning- } \\
\text { making and restoration, active } \\
\text { coping, cognitive flexibility, } \\
\text { spirituality, and self-efficacy. }\end{array}$ & $\begin{array}{l}\text { Active-duty and reserve members of the military and veterans (Johnson } \\
\text { 2011) }\end{array}$ & 1 & $\begin{array}{l}\text { 2011, United } \\
\text { States }\end{array}$ \\
\hline $\begin{array}{l}\text { Sense of Coherence } \\
\text { Scale }\end{array}$ & $\begin{array}{l}\text { Based on Antonovsky's } \\
\text { salutogenesis framework. Used } \\
\text { to measure } 3 \text { dimensions: } \\
\text { comprehension, } \\
\text { meaningfulness, and } \\
\text { manageability. }\end{array}$ & 33 languages in 32 countries (eg, Eriksson 2005) & 51 & 1993, Israel \\
\hline $\begin{array}{l}\text { Solution-Focused } \\
\text { Inventory }\end{array}$ & $\begin{array}{l}\text { Way to measure people's } \\
\text { resources and their own } \\
\text { resilience as a means of } \\
\text { promoting a positive change. }\end{array}$ & $\begin{array}{l}\text { Australian adult population (Grant 2012); Chinese college students } \\
\text { (Yang 2015) }\end{array}$ & 3 & 2011, Australia \\
\hline Values in Action & $\begin{array}{l}\text { Measures } 24 \text { character } \\
\text { strengths (Macdonald 2008). }\end{array}$ & $\begin{array}{l}\text { General adult population (Macdonald 2008); Spanish population } \\
\text { (Azañedo 2014); Indian (Choubisa 2011); South African (du Plessis } \\
\text { 2015); Chinese (Duan 2011) (Duan 2012); African (Khumalo 2008); } \\
\text { Israeli (Littman-Ovadia 2008); Japanese (Otake 2005) }\end{array}$ & 20 & $\begin{array}{l}\text { 2004, United } \\
\text { States }\end{array}$ \\
\hline
\end{tabular}

\footnotetext{
${ }^{\mathrm{a}} \mathrm{A}$ list of the publications cited in this table is in the Appendix.
} 
Table 3. Inner, External, and Personality Strengths Constructs Found in Assessments of Patient Strengths Instruments

\begin{tabular}{|c|c|c|c|}
\hline Domain & Construct & Source(s) & Definition \\
\hline \multicolumn{4}{|c|}{ Inner Strengths Constructs } \\
\hline \multicolumn{4}{|l|}{ Relational strength } \\
\hline \multirow[t]{5}{*}{ Perceived relations } & Belonging support & $\begin{array}{l}\text { Interpersonal Support } \\
\text { Evaluation List }\end{array}$ & $\begin{array}{l}\text { Perception of the availability of others for social interactions, and } \\
\text { that one is a part of a group. }\end{array}$ \\
\hline & Compensating experiences & $\begin{array}{l}\text { Baruth Protective Factors } \\
\text { Inventory }\end{array}$ & $\begin{array}{l}\text { A sense that one's informal networks provide opportunities or } \\
\text { supplemental support systems above and beyond those in their } \\
\text { formal networks. }\end{array}$ \\
\hline & Love & Values in Action & The commitment to others or a commitment to what one does. \\
\hline & Self-esteem support & $\begin{array}{l}\text { Interpersonal Support } \\
\text { Evaluation List }\end{array}$ & $\begin{array}{l}\text { The perception that one has other people with whom one compares } \\
\text { positively. }\end{array}$ \\
\hline & Reward dependence $^{a}$ & $\begin{array}{l}\text { Temperament and Character } \\
\text { Inventory }\end{array}$ & $\begin{array}{l}\text { Sentimentality, social sensitivity, attachment, and dependence on } \\
\text { the approval of others. Characteristically sensitive, socially } \\
\text { dependent, and sociable. }\end{array}$ \\
\hline \multirow[t]{6}{*}{$\begin{array}{l}\text { Perceived ability to get along } \\
\text { with others }\end{array}$} & Consensuality & $\begin{array}{l}\text { California Psychological } \\
\text { Inventory }\end{array}$ & $\begin{array}{l}\text { The perception of adhering to social norms when engaging in } \\
\text { interpersonal interactions. }\end{array}$ \\
\hline & Family cohesion & Resilience Scale for Adults & $\begin{array}{l}\text { Having shared values, mutual appreciation, and support between } \\
\text { family members. }\end{array}$ \\
\hline & Relating to others & 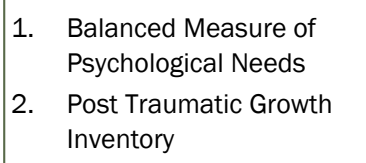 & $\begin{array}{l}\text { One's feeling of more compassion and empathy for others after } \\
\text { adversity such as trauma or loss. A feeling of connection or } \\
\text { closeness with important others. }\end{array}$ \\
\hline & $\begin{array}{l}\text { Social competence (ie, positive } \\
\text { relations) }\end{array}$ & $\begin{array}{ll}\text { 1. } & \text { Psychological Well-being } \\
\text { Questionnaire } \\
\text { 2. } & \text { Resilience Scale for } \\
& \text { Adults } \\
\text { 3. } & \text { Resistance to Trauma } \\
\text { Test }\end{array}$ & $\begin{array}{l}\text { A general positive orientation, agreeableness, and sociability toward } \\
\text { others. }\end{array}$ \\
\hline & Social skills and relationships & Values in Action & $\begin{array}{l}\text { An assessment of the behaviors that facilitate the interactions with } \\
\text { family members, friends, colleagues, and acquaintances, as well as } \\
\text { how one interacts with one's environment. }\end{array}$ \\
\hline & Cooperativeness $^{a}$ & $\begin{array}{l}\text { Temperament and Character } \\
\text { Inventory }\end{array}$ & $\begin{array}{l}\text { The extent to which one conceives oneself as an integral part of } \\
\text { human society. Characteristically tolerant, empathetic, } \\
\text { compassionate, supportive, or principled. }\end{array}$ \\
\hline \multirow[t]{4}{*}{ Transcendence } & Connectedness & Inner Strength Questionnaire & $\begin{array}{l}\text { The connection to others such as family, society, and nature; having } \\
\text { a spiritual dimension to life and being able to transcend oneself. }\end{array}$ \\
\hline & Death acceptances & Life Attitude Profile & When a person transcends the fear of death. \\
\hline & Gratitude & Values in Action & $\begin{array}{l}\text { An inclination to acknowledge goodness in life and recognizing the } \\
\text { source of goodness is outside of oneself. }\end{array}$ \\
\hline & Spiritual strength & $\begin{array}{ll}\text { 1. } & \text { Connor-Davidson } \\
\text { 2. } & \text { Resilience Scale } \\
\text { 2ost Traumatic Growth } & \text { Inventory } \\
\text { 3. } & \text { Values in Action } \\
\text { 4. } & \text { Brief COPE } \\
\text { 5. } & \text { Response to Stressful } \\
& \text { Experiences Scale }\end{array}$ & $\begin{array}{l}\text { Having an understanding of spiritual matters, coherent beliefs } \\
\text { about the higher purpose and meaning in the universe. Knowing } \\
\text { where one fits in the larger scheme, having beliefs about the } \\
\text { meaning of life that shape conduct and provide comfort. }\end{array}$ \\
\hline
\end{tabular}

\footnotetext{
${ }^{a}$ These constructs are part of instruments that did not pass the validity assessment stage but had unique constructs not found in validated instruments.
} 
(continued)

Table 3. Inner, External, and Personality Strengths Constructs Found in Assessments of Patient Strengths Instruments

\begin{tabular}{|c|c|c|c|}
\hline Domain & Construct & Source(s) & Definition \\
\hline & Care $^{a}$ & $\begin{array}{l}\text { Psychosocial Inventory of Ego } \\
\text { Strengths }\end{array}$ & $\begin{array}{l}\text { One's inclination to take care of others, and commitment toward } \\
\text { what one cares about and cares to do. }\end{array}$ \\
\hline & Self-transcendence ${ }^{a}$ & $\begin{array}{l}\text { Temperament and Character } \\
\text { Inventory }\end{array}$ & $\begin{array}{l}\text { The extent to which one considers oneself as being an integral part } \\
\text { of the universe as a whole. Characteristically spiritual, } \\
\text { unpretentious, humble, or fulfilled. }\end{array}$ \\
\hline \multicolumn{4}{|l|}{ Motivational strength } \\
\hline \multirow[t]{2}{*}{ Optimism } & Hope & 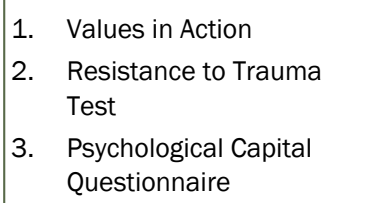 & $\begin{array}{l}\text { A belief and confidence that wishes will be obtained despite } \\
\text { obstacles and barriers. }\end{array}$ \\
\hline & New possibilities & $\begin{array}{l}\text { Post Traumatic Growth } \\
\text { Inventory }\end{array}$ & $\begin{array}{l}\text { How one develops new interests, is future thinking, or appreciates } \\
\text { new opportunities as they arise. }\end{array}$ \\
\hline \multirow[t]{3}{*}{ Meaning of life } & Appreciation of life & 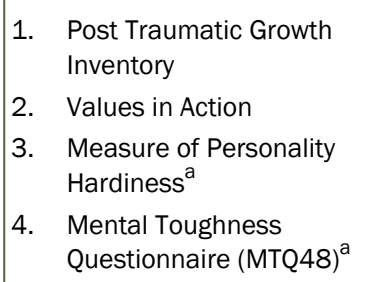 & $\begin{array}{l}\text { A greater understanding for one's own personal values and } \\
\text { meaning of life. Ability to recognize and admire the beauty in various } \\
\text { areas of life such as art, science, and one's own life. }\end{array}$ \\
\hline & Meaningfulness & 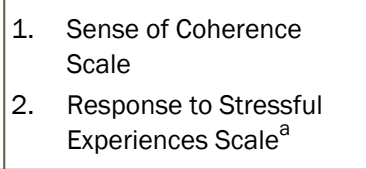 & One's ability to find meaning in a situation. \\
\hline & Purpose & $\begin{array}{ll}\text { 1. } & \text { Psychological Well-being } \\
\text { Questionnaire } \\
\text { 2. }\end{array}$ & $\begin{array}{l}\text { A belief in the meaning of one's life and one's past and present } \\
\text { actions. }\end{array}$ \\
\hline \multirow[t]{3}{*}{ Self-regulation } & Goal orientation & Solution-Focused Inventory & Engaging with goal-setting and self-management behaviors. \\
\hline & Personal growth & $\begin{array}{l}\text { Psychological Well-being } \\
\text { Questionnaire }\end{array}$ & A sense of self-improvement or personal expansion over time. \\
\hline & Prudence & Values in Action & $\begin{array}{l}\text { One's inclination for far-sighted planning, short-term understanding, } \\
\text { and goal-directed planning. }\end{array}$ \\
\hline \multirow[t]{2}{*}{ Self-efficacy } & Self-efficacy & 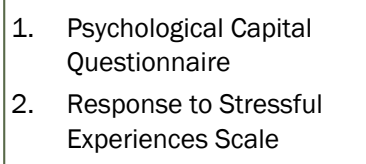 & Confidence in one's ability to be motivated to take action. \\
\hline & Confidence & $\begin{array}{l}\text { Mental Toughness } \\
\text { Questionnaire (MTQ48) }\end{array}$ & $\begin{array}{l}\text { Sense of self-belief and unshakeable faith considering one's ability } \\
\text { to achieve success. }\end{array}$ \\
\hline \multicolumn{4}{|l|}{ Protective strength } \\
\hline \multirow[t]{3}{*}{ Protective strength } & Active coping & $\begin{array}{l}\text { Response to Stressful } \\
\text { Situations Scale }\end{array}$ & $\begin{array}{l}\text { An ability to engage in behaviors and thoughts that alter both } \\
\text { internal and external sources of stress. }\end{array}$ \\
\hline & Behavioral disengagement & Brief COPE & $\begin{array}{l}\text { Ability to give up or reduce negative behaviors or stressors that may } \\
\text { inhibit one's ability to reach goals. }\end{array}$ \\
\hline & Emotional stability & 1. Big Five Personality & How one readily overcomes setbacks, disengages negative \\
\hline
\end{tabular}

\footnotetext{
${ }^{a}$ These constructs are part of instruments that did not pass the validity assessment stage but had unique constructs not found in validated instruments.
} 
(continued)

Table 3. Inner, External, and Personality Strengths Constructs Found in Assessments of Patient Strengths Instruments

\begin{tabular}{|c|c|c|c|}
\hline Domain & Construct & Source(s) & Definition \\
\hline & & 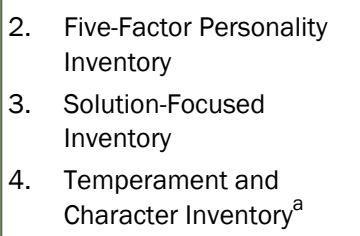 & thoughts, and remains in the same mood in various situations. \\
\hline & $\begin{array}{l}\text { Emotional intelligence and } \\
\text { internal control }\end{array}$ & Resistance to Trauma Test & $\begin{array}{l}\text { Having the knowledge and ability to handle needs and control } \\
\text { impulses for various situations. }\end{array}$ \\
\hline & Having few stressors & $\begin{array}{l}\text { Baruth Protective Factors } \\
\text { Inventory }\end{array}$ & $\begin{array}{l}\text { Number of stressors experienced in one's life, with the assumption } \\
\text { that those who are resilient experience fewer stressors. }\end{array}$ \\
\hline & Trust, tolerance & $\begin{array}{l}\text { Connor-Davidson Resilience } \\
\text { Scale }\end{array}$ & $\begin{array}{l}\text { One's tolerance of negative affect or the strengthening effects of } \\
\text { stress, as well as trust in one's own instincts. }\end{array}$ \\
\hline \multicolumn{4}{|c|}{ Volitional strength } \\
\hline \multirow[t]{2}{*}{ Independence } & Autonomy & 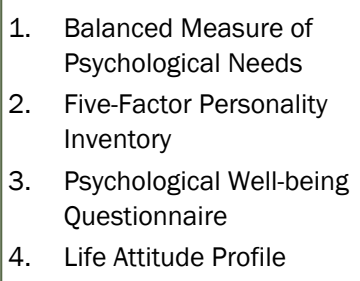 & $\begin{array}{l}\text { A sense of independence for choices and experiences of volition } \\
\text { and self-regulation; feelings of personal agency. }\end{array}$ \\
\hline & Control & 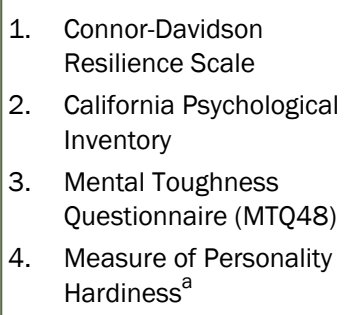 & A sense of control in life. \\
\hline \multirow[t]{5}{*}{ Determination } & Bravery & Values in Action & $\begin{array}{l}\text { Courage or ability to overcome fear, composed of cognitions, } \\
\text { emotions, motivations, and decisions. }\end{array}$ \\
\hline & Courage & Values in Action & $\begin{array}{l}\text { One's ability to use emotional strength to support and drive } \\
\text { achievement, even when faced with adversity. }\end{array}$ \\
\hline & Persistence & Values in Action & $\begin{array}{l}\text { Maintenance of one's behavior despite perceived barriers, } \\
\text { frustration, and fatigue. Remaining determined and industrious. }\end{array}$ \\
\hline & Firmness $^{a}$ & Inner Strength Questionnaire & $\begin{array}{l}\text { Ability to take responsibility for oneself and others, and to deal with } \\
\text { difficulties as they arise. }\end{array}$ \\
\hline & Will $^{\mathrm{a}}$ & $\begin{array}{l}\text { Psychosocial Inventory of Ego } \\
\text { Strengths }\end{array}$ & $\begin{array}{l}\text { One's ability to exercise free choice and demonstrate self-restraint } \\
\text { and self-control. }\end{array}$ \\
\hline Self-healing & Personal strength (resilience) & 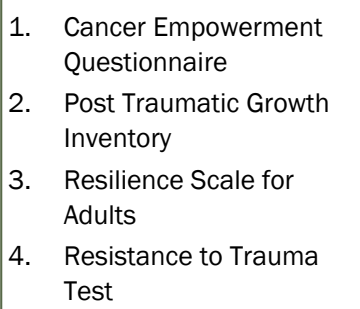 & $\begin{array}{l}\text { The ability to bounce back from adversity, increased resiliency, and } \\
\text { view of one's current strengths as well as one's belief in one's } \\
\text { ability to realize plans and goals. }\end{array}$ \\
\hline
\end{tabular}

\footnotetext{
${ }^{a}$ These constructs are part of instruments that did not pass the validity assessment stage but had unique constructs not found in validated instruments.
} 
(continued)

Table 3. Inner, External, and Personality Strengths Constructs Found in Assessments of Patient Strengths Instruments

\begin{tabular}{|c|c|c|c|}
\hline \multirow[t]{3}{*}{ Domain } & Construct & Source(s) & Definition \\
\hline & & 5. General resilience ${ }^{a}$ & \\
\hline & Physical self-spirit & Inner Strength Questionnaire & $\begin{array}{l}\text { One's ability to heal through activities, involvement, emotional } \\
\text { honesty, and celebration. }\end{array}$ \\
\hline \multicolumn{4}{|c|}{ Self-awareness strength } \\
\hline \multirow[t]{7}{*}{ Self-awareness } & Coherence & Life Attitude Profile & A consistent understanding of life, others, and oneself. \\
\hline & Comprehensibility & Sense of Coherence Scale & $\begin{array}{l}\text { The ability to be aware and understand what is happening in the } \\
\text { environment. }\end{array}$ \\
\hline & Fidelity & Resistance to Trauma Test & $\begin{array}{l}\text { An internalized preoccupation with being genuine or fair to oneself } \\
\text { and others in terms of values, ethics, and beliefs. }\end{array}$ \\
\hline & Internal congruency & Resistance to Trauma Test & $\begin{array}{l}\text { How consistently one acts vis-à-vis how one thinks and what one } \\
\text { intends. }\end{array}$ \\
\hline & Mental self-spirit & Inner Strength Questionnaire & Ability to learn about one's self. \\
\hline & Perspective & Values in Action & $\begin{array}{l}\text { One's high level of knowledge and capacity to give and to recognize } \\
\text { and weigh multiple sides before making decisions. }\end{array}$ \\
\hline & Self-acceptance & $\begin{array}{l}\text { Psychological Well-being } \\
\text { Questionnaire }\end{array}$ & A positive attitude toward oneself and past choices. \\
\hline \multicolumn{4}{|c|}{ External Strengths Constructs } \\
\hline \multirow[t]{7}{*}{ Social resources } & Affect & $\begin{array}{l}\text { Norbeck Social Support } \\
\text { Questionnaire }\end{array}$ & $\begin{array}{l}\text { The perception that the individual's network gives love, respect, and } \\
\text { admiration. }\end{array}$ \\
\hline & Affirmation & $\begin{array}{l}\text { Norbeck Social Support } \\
\text { Questionnaire }\end{array}$ & $\begin{array}{l}\text { The perception that others agree with the individual's actions and } \\
\text { serve as confidants. }\end{array}$ \\
\hline & Aid & $\begin{array}{l}\text { Norbeck Social Support } \\
\text { Questionnaire }\end{array}$ & $\begin{array}{l}\text { The perception that others are able to provide financial or physical } \\
\text { help to complete tasks. }\end{array}$ \\
\hline & Appraisal support & $\begin{array}{l}\text { Interpersonal Support } \\
\text { Evaluation List }\end{array}$ & $\begin{array}{l}\text { The perceived availability of someone to talk to about important, } \\
\text { personal issues. }\end{array}$ \\
\hline & Social support & $\begin{array}{ll}\text { 1. } & \text { Cancer Empowerment } \\
\text { 2. } & \text { Questionnaire } \\
\text { 2. } & \text { Brief COPE } \\
\text { 3. } & \text { Chronic Illness Resources } \\
& \text { Survey }\end{array}$ & $\begin{array}{l}\text { Perceived support from those who are close to the individual, either } \\
\text { in the form of information or emotions. }\end{array}$ \\
\hline & Social resources & $\begin{array}{ll}\text { 1. } & \text { Baruth Protective Factors } \\
\text { Inventory } \\
\text { 2. } & \begin{array}{l}\text { Cancer Empowerment } \\
\text { Questionnaire }\end{array} \\
\text { 3. } & \text { Resilience Scale for } \\
\text { Adults }\end{array}$ & $\begin{array}{l}\text { One's community or the type and quality of the social support and } \\
\text { tangible or intangible resources received. }\end{array}$ \\
\hline & Tangible assets support & $\begin{array}{l}\text { Interpersonal Support } \\
\text { Evaluation List }\end{array}$ & Perceived availability of material aid. \\
\hline \multirow[t]{3}{*}{ Institutional support } & Community organizations & $\begin{array}{l}\text { Chronic Illness Resources } \\
\text { Survey }\end{array}$ & $\begin{array}{l}\text { Having access to and participating in national and local } \\
\text { organizations that support health. Examples include churches, } \\
\text { employers, and other local volunteer organizations. }\end{array}$ \\
\hline & Community supports & $\begin{array}{l}\text { Chronic Illness Resources } \\
\text { Survey }\end{array}$ & $\begin{array}{l}\text { Having access to a community that supports health. Includes } \\
\text { characteristics such as public transportation, community } \\
\text { organizations that provide health information, and healthy food } \\
\text { options. }\end{array}$ \\
\hline & Employment support & Chronic Illness Resources & Having an employer that supports health. Characteristics include \\
\hline
\end{tabular}

\footnotetext{
${ }^{a}$ These constructs are part of instruments that did not pass the validity assessment stage but had unique constructs not found in validated instruments.
} 
(continued)

Table 3. Inner, External, and Personality Strengths Constructs Found in Assessments of Patient Strengths Instruments

\begin{tabular}{|c|c|c|c|}
\hline Domain & Construct & Source(s) & Definition \\
\hline & Employment support & $\begin{array}{l}\text { Chronic Illness Resources } \\
\text { Survey }\end{array}$ & $\begin{array}{l}\text { Having an employer that supports health. Characteristics include } \\
\text { flexible work schedules, access to workplace wellness facilities, and } \\
\text { policies that support illness management. }\end{array}$ \\
\hline & Health care support & $\begin{array}{ll}\text { 1. } & \text { Cancer Empowerment } \\
\text { Questionnaire } \\
\text { 2. Chronic Illness Resources } \\
\text { Survey }\end{array}$ & $\begin{array}{l}\text { A perception of a good and collaborative relationship with health } \\
\text { care staff as well as the ability to obtain medical information from } \\
\text { health care staff. }\end{array}$ \\
\hline & Media and policy resources & $\begin{array}{l}\text { Chronic Illness Resources } \\
\text { Survey }\end{array}$ & $\begin{array}{l}\text { Extent that media and policy support chronic illness management. } \\
\text { Includes health insurance coverage, medical costs, and positive } \\
\text { sources of information regarding health from television, radio, } \\
\text { billboards, and the internet. }\end{array}$ \\
\hline & Neighborhood supports & $\begin{array}{l}\text { Chronic Illness Resources } \\
\text { Survey }\end{array}$ & $\begin{array}{l}\text { Having access to an environment that supports health. Includes } \\
\text { characteristics such as healthy food choice, safe parks, and friendly } \\
\text { neighbors. }\end{array}$ \\
\hline \multicolumn{4}{|c|}{ Personality Constructs } \\
\hline \multicolumn{4}{|l|}{ General personality traits } \\
\hline \multirow[t]{2}{*}{ Intelligence } & Intellectual strengths & Values in Action & $\begin{array}{l}\text { One's intellectual strengths, creativity, curiosity, and judgment, as } \\
\text { well as a love for learning and appreciation of beauty. }\end{array}$ \\
\hline & Wisdom & Values in Action & $\begin{array}{l}\text { Positive reflection on one's past and present, and a maturity in } \\
\text { judgment. }\end{array}$ \\
\hline \multirow[t]{6}{*}{$\begin{array}{l}\text { Approach to interaction with } \\
\text { others }\end{array}$} & Agreeableness & $\begin{array}{l}\text { 1. Big Five Personality } \\
\text { 2. Five-Factor Personality } \\
\text { Inventory }\end{array}$ & $\begin{array}{l}\text { Respect for others; ability to take others' interests into account, and } \\
\text { to make compromises. }\end{array}$ \\
\hline & Extraversion & 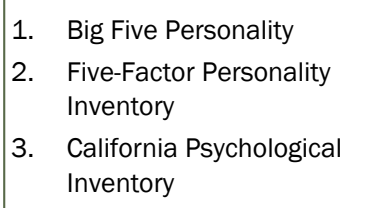 & Being connected and sociable with others. \\
\hline & Flexibility & 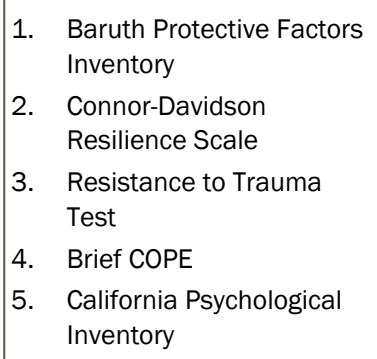 & $\begin{array}{l}\text { One's life trajectory and the openness to changing life } \\
\text { circumstances as needed. }\end{array}$ \\
\hline & Humility & Values in Action & $\begin{array}{l}\text { An accurate self-assessment, recognition of limitations, and keeping } \\
\text { accomplishments in perspective, as well as forgetting of the self. }\end{array}$ \\
\hline & Leadership & Values in Action & $\begin{array}{l}\text { The inclination to encourage a group of people and preserve } \\
\text { harmony within groups. }\end{array}$ \\
\hline & Teamwork & Values in Action & $\begin{array}{l}\text { How one excels in a team, how dedicated one is in a team, how one } \\
\text { shares and works hard for the success of the team. }\end{array}$ \\
\hline Positivity & Humor & $\begin{array}{ll}\text { 1. Values in Action } \\
\text { 2. } \\
\text { Resistance to Trauma } \\
\text { Test }\end{array}$ & $\begin{array}{l}\text { Ability to make oneself and others laugh as well as provide a lighter } \\
\text { perspective on events. }\end{array}$ \\
\hline
\end{tabular}

\footnotetext{
${ }^{a}$ These constructs are part of instruments that did not pass the validity assessment stage but had unique constructs not found in validated instruments.
} 
(continued)

Table 3. Inner, External, and Personality Strengths Constructs Found in Assessments of Patient Strengths Instruments

\begin{tabular}{|c|c|c|c|}
\hline Domain & Construct & Source(s) & Definition \\
\hline & & 3. Brief COPE & \\
\hline & Zest & 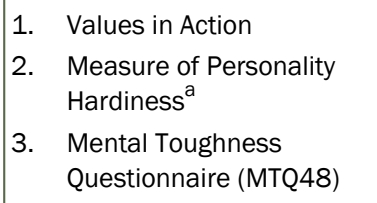 & One's approach to all experiences with excitement and energy. \\
\hline \multirow[t]{5}{*}{ Justice } & Fairness & Values in Action & $\begin{array}{l}\text { An assessment of where one's fairness falls under justice. One's } \\
\text { capacity to reason and make judgments. }\end{array}$ \\
\hline & Forgiveness & Values in Action & $\begin{array}{l}\text { Having kindness and compassion toward others, as well as one's } \\
\text { inclinations toward mercy and temperance. }\end{array}$ \\
\hline & Honesty & Values in Action & $\begin{array}{l}\text { A representation of the internal states, intentions, and } \\
\text { commitments, both in public and private domains. }\end{array}$ \\
\hline & Judgment & Values in Action & $\begin{array}{l}\text { The ability to examine all aspects of a problem and weigh relevant } \\
\text { evidence equally. }\end{array}$ \\
\hline & Kindness & Values in Action & $\begin{array}{l}\text { A belief that others are worthy of attention and affirmation for their } \\
\text { own sake as human beings. }\end{array}$ \\
\hline \multirow[t]{4}{*}{$\begin{array}{l}\text { Approach toward learning } \\
\text { and new experiences }\end{array}$} & Curiosity & $\begin{array}{ll}\text { 1. } & \text { Values in Action } \\
\text { 2. } & \text { Big Five Personality } \\
\text { 3. } & \text { Life Attitude Profile }\end{array}$ & $\begin{array}{l}\text { Wanting to explore and learn about new topics or ideas; being open } \\
\text { to new experiences. }\end{array}$ \\
\hline & Creativity & Values in Action & $\begin{array}{l}\text { The ability to think of new ideas or ways to do things and to } \\
\text { influence the life course. }\end{array}$ \\
\hline & Love of learning & Values in Action & The inclination to enjoy engaging with new information and skills. \\
\hline & Novelty seeking ${ }^{a}$ & $\begin{array}{l}\text { Temperament and Character } \\
\text { Inventory }\end{array}$ & $\begin{array}{l}\text { Response to novel activities, impulsiveness to cues for rewards, and } \\
\text { active avoidance of frustration. Characteristically quick-tempered, } \\
\text { curious, easily bored. }\end{array}$ \\
\hline \multicolumn{4}{|l|}{ Resourcefulness } \\
\hline \multirow[t]{5}{*}{ Self-management skills } & Conscientiousness & $\begin{array}{ll}\text { 1. } & \text { Big Five Personality } \\
\text { 2. } & \text { Five-Factor Personality } \\
\text { Inventory }\end{array}$ & How one follows a routine and does things according to a plan. \\
\hline & Manageability & Sense of Coherence Scale & $\begin{array}{l}\text { One's ability to manage one's own situation either independently or } \\
\text { with the help of important others. }\end{array}$ \\
\hline & Planning & Brief COPE & $\begin{array}{l}\text { Ability to think about how to address and create strategies to } \\
\text { mitigate challenges in one's life. }\end{array}$ \\
\hline & Self-regulation & Values in Action & Ability to control and monitor one' behaviors and emotions. \\
\hline & Having a structured style & Resilience Scale for Adults & $\begin{array}{l}\text { Being able to follow a routine, even if situations are challenging, as } \\
\text { well as being organized and having clear goals and plans. }\end{array}$ \\
\hline \multirow[t]{2}{*}{ Ability to use resources } & Resource activation & \begin{tabular}{|ll} 
1. & Brief COPE \\
2. & $\begin{array}{l}\text { Solution-Focused } \\
\text { Inventory }\end{array}$ \\
3. & Chronic Illness Resources \\
& Survey \\
4. & Response to Stressful \\
Experiences Scale
\end{tabular} & $\begin{array}{l}\text { The ability to determine solutions to problems or find resources to } \\
\text { address problems. }\end{array}$ \\
\hline & Self-directedness ${ }^{a}$ & Temperament and Character & The extent to which one is responsible, reliable, resourceful, goal- \\
\hline
\end{tabular}

\footnotetext{
${ }^{a}$ These constructs are part of instruments that did not pass the validity assessment stage but had unique constructs not found in validated instruments.
} 


\section{PREVENTING CHRONIC DISEASE}

VOLUME 18, E41

PUBLIC HEALTH RESEARCH, PRACTICE, AND POLICY

APRIL 2021

(continued)

Table 3. Inner, External, and Personality Strengths Constructs Found in Assessments of Patient Strengths Instruments

\begin{tabular}{|c|c|c|c|}
\hline Domain & Construct & Source(s) & Definition \\
\hline & & Inventory & oriented, and self-confident. \\
\hline \multirow[t]{3}{*}{ Knowledge about resources } & Competence & $\begin{array}{l}\text { 1. Balanced Measure of } \\
\text { Psychological Needs } \\
\text { 2. } \begin{array}{l}\text { Connor-Davidson } \\
\text { Resilience Scale }\end{array}\end{array}$ & $\begin{array}{l}\text { An application of one's skills, abilities, and intelligence on the } \\
\text { completion of a task. A demonstrated mastery of a skill or concept. }\end{array}$ \\
\hline & Environmental mastery & $\begin{array}{l}\text { Psychological Well-being } \\
\text { Questionnaire }\end{array}$ & $\begin{array}{l}\text { Ability and competence to manage one's environment and external } \\
\text { activities. }\end{array}$ \\
\hline & Knowing and searching & Inner Strength Questionnaire & $\begin{array}{l}\text { The ability to face potential diagnoses and subsequently to explore } \\
\text { ways to use one's strengths. }\end{array}$ \\
\hline
\end{tabular}

${ }^{a}$ These constructs are part of instruments that did not pass the validity assessment stage but had unique constructs not found in validated instruments. 


\section{Appendix}

Following is a listing of studies cited in Table 2 of the article.

\section{Balanced Measure of Psychological Needs}

Sheldon KM, Hilpert JC. The balanced measure of psychological needs (BMPN) scale: an alternative domain general measure of need satisfaction. Motiv Emot 2012;36(4):439-51.

\section{Baruth Protective Factors Inventory}

Baruth KE, Carroll JJ. A formal assessment of resilience: the Baruth Protective Factors Inventory. J Individ Psychol (1998) 2002;58(3):235-44.

\section{Big Five Personality}

Barrick MR, Mount MK. The Big Five personality dimensions and job performance: a metaanalysis. Pers Psychol 1991;44(1):1-26.

Benet-Martínez V, John OP. Los Cinco Grandes across cultures and ethnic groups: multitrait-multimethod analyses of the Big Five in Spanish and English. J Pers Soc Psychol 1998;75(3):729-50.

Fossati A, Borroni S, Marchione D, Maffei C. The big five inventory (BFI). Eur J Psychol Assess 2011;27(1):50-8.

Smits IA, Dolan CV, Vorst HC, Wicherts JM, Timmerman ME. Cohort differences in Big Five personality factors over a period of 25 years. J Pers Soc Psychol 2011;100(6):1124-38.

Van Heck GL, Perugini M, Caprara G-V, Fröger J. The Big Five as tendencies in situations. Pers Individ Dif 1994;16(5):715-31.

Pulver A, Allik J, Pulkkinen L, Hämäläinen M. A Big Five personality inventory in two non-IndoEuropean languages. Eur J Pers 1995;9(2):109-24.

Strelau J, Zawadzki B. The formal characteristics of behaviour - Temperament inventory (FCB - TI): validity studies. Eur J Pers 1995;9(3):207-29.

Wada S. Construction of the Big Five Scales of personality trait terms and concurrent validity with NPI. Shinrigaku Kenkyu 1996;67(1):61-7.

El-Ansarey B. The psychometric properties of NEO five-factor inventory (NEO-FFI-S) based on the Kuwaiti society. Derasat Nafseyah 1997;7:277-310.

Nunes CHSS, Hutz CS. Development and validation of an Agreeableness scale in the Big Five personality model. Psicol Reflex Crit 2007;20(1):20-5.

Hauck Filho N, de Lara Machado W, Teixeira MAP, Bandeira DR. Evidencias de validade de marcadores reduzidos para a avaliacao da personalidade no modelo dos Cinco Grandes Fatores. Psicologia: Teoria e Pesquisa 2012;28(4):417-23. Portuguese.

Rammstedt B. The 10-item Big Five Inventory: norm values and investigation of sociodemographic effects based on a German population representative sample. Eur J Psychol Assess 2007;23(3):193-201.

Mlacić B. National taxonomies, adjective markers and inventories: Three directions of application of the lexical approach to personality. Roczniki Psychologiczne 2008;11(1):152-60

Hrebičková M. Questionnaire in the Czech context. Stud Psychol (Bratisl) 2010;52:(3):165-77.

Karaman NG, Dogan T, Coban AE. A study to adapt the big five inventory to Turkish. Procedia Soc Behav Sci 2010;2(2):2357-9.

Gençöz T, Öcül Ö. Examination of personality characteristics in a Turkish sample: development of Basic Personality Traits Inventory. J Gen Psychol 2012;139(3):194-216.

Morsünbül Ü. The association of internet addiction with attachment styles, personality traits, loneliness and life satisfaction. Journal of Human Sciences 2014;11(1):357-72.

Huang Y, Wang L. Sex differences in framing effects across task domain. Pers Individ Dif 2010;48(5):649-53.

The opinions expressed by authors contributing to this journal do not necessarily reflect the opinions of the U.S. Department of Health and Human Services, the Public Health Service, the Centers for Disease Control and Prevention, or the authors' affiliated institutions. 
Wang W, editor. How personality affects continuance intention: an empirical investigation of instant messaging. Proceedings of the Pacific Asia Conference on Information Systems (PACIS); 2010. No. 113.

Shi M, Liu L, Wang ZY, Wang L. The mediating role of resilience in the relationship between big five personality and anxiety among Chinese medical students: a cross-sectional study. PLoS One 2015;10(3):e0119916.

Ledesma RD, Sánchez R, Díaz-Lázaro CM. Adjective checklist to assess the big five personality factors in the Argentine population. J Pers Assess 2011;93(1):46-55.

Fan J, Zhu X-z, Tang L-I, Wang Y-p, Li L, Yang Y, et al. Reliability and validity of Chinese Big Five Personality inventory brief version in breast cancer women. Chinese Journal of Clinical Psychology 2013;21(5):783-5.

\section{Brief COPE}

Carver CS. You want to measure coping but your protocol's too long: consider the brief COPE. Int J Behav Med 1997;4(1):92-100.

Müller W.Lebe jetzt-einfach sein. Mainz (DE): Matthias-Grünewald-Verlag; 2003.

Doron J, Trouillet R, Gana K, Boiché J, Neveu D, Ninot G. Examination of the hierarchical structure of the Brief COPE in a French sample: empirical and theoretical convergences. J Pers Assess 2014;96(5):567-75.

Muhonen T, Torkelson E. Kortversioner av frågeformulär inom arbets-och hälsopsykologi - om att mäta coping och optimism. Nord Psykol 2005;57(3):288-97.

Yusoff N, Low WY, Yip CH. Reliability and validity of the Brief COPE Scale (English version) among women with breast cancer undergoing treatment of adjuvant chemotherapy: a Malaysian study. Med J Malaysia 2010;65(1):41-4.

Kimemia M, Asner-Self KK, Daire AP. An exploratory factor analysis of the Brief COPE with a sample of Kenyan caregivers. Int J Adv Couns 2011;33(3):149-60.

Snell DL, Siegert RJ, Hay-Smith EJC, Surgenor LJ. Factor structure of the Brief COPE in people with mild traumatic brain injury. J Head Trauma Rehabil 2011;26(6):468-77.

Mejorada REO, Tufiño MAT, Sierra AV, Guerrero OT, Rosas AR, Sosa JJS. Afrontamiento en pacientes con cáncer de mama en radioterapia: análisis de la Escala COPE Breve. Psicología y Salud 2013;23(1):55-62.

Mohanraj R, Jeyaseelan V, Kumar S, Mani T, Rao D, Murray KR, et al. Cultural adaptation of the Brief COPE for persons living with HIV/AIDS in southern India. AIDS Behav 2015;19(2):341-51.

Su XY, Lau JT, Mak WW, Choi KC, Feng TJ, Chen X, et al. A preliminary validation of the Brief COPE instrument for assessing coping strategies among people living with HIV in China. Infect Dis Poverty 2015;4(1):41.

\section{California Psychological Inventory}

Gough HG. The construction of a personality scale to predict scholastic achievement. J Appl Psychol 1953;37(5):361-6.

Dicken CF. Convergent and discriminant validity of the California Psychological Inventory. Educ Psychol Meas 1963;23(3):449-59.

Darbes A, Mottesheard N, editors. A validity check of selected cluster scores of the California Psychological Inventory tests of 239 college students. Proceedings of the West Virginia Academy of Science 1964;36:191-4.

Goodstein LD, Schrader WJ. An empirically-derived managerial key for the California Psychological Inventory. J Appl Psychol 1963;47(1):42-5.

Gough HG. A managerial potential scale for the California Psychological Inventory. J Appl Psychol 1984;69(2):233-40.

Knapp RR. Personality correlates of delinquency rate in a Navy sample. J Appl Psychol 1963;47(1):68-71.

Gough HG. Academic achievement in high school as predicted from the California Psychological Inventory. J Educ Psychol 1964;55(3):174-80.

Gough HG. Graduation from high school as predicted from the California Psychological Inventory. Psychol Sch 1966;3(3):208-16.

The opinions expressed by authors contributing to this journal do not necessarily reflect the opinions of the U.S. Department of Health and Human Services, the Public Health Service, the Centers for Disease Control and Prevention, or the authors' affiliated institutions. 
Chapuis C, Quintard G, Wourms J. A new personality inventory: the CPI (California Psychological Inventory). Bull Psychol 1970;24(16-18):997-1004.

Nishiyama T. Cross-cultural invariance of California Psychological Inventory. Psychologia 1973;16(2):75-84.

Nishiyama T. Validation of the CPI femininity scale in Japan. J Cross Cult Psychol 1975;6(4):482-9.

Rosen A-S, Schalling D. On the validity of the California Psychological Inventory Socialization scale: a multivariate approach. J Consult Clin Psychol 1974;42(6):757-65.

Gough HG. Estimation of locus-of-control scores from the California Psychological Inventory. Psychol Rep 1974;35(1 Pt 2):343-8.

Cohen A, Farley FH. The common-item problem in measurement: effects on cross-cultural invariance of personality inventory structure. Educ Psychol Meas 1977;37(3):757-60.

Pitariu H, Helmine H. Investigarea personalității cu ajutorul Inventarului Psihologic California (CPI). Rev Psihol 1980;26(4):461-73.

Pitariu H. Validation of the CPI femininity scale in Romania. J Cross Cult Psychol 1981;12(1):111-7.

Ahmed I. Initial psychometric evaluation of URDU version of California Psychological Inventory (CPI). Pak J Psychol Res 1986;(June 22):3-16.

Torki MA. The CPI femininity scale in Kuwait and Egypt. J Pers Assess 1988;52(2):247-53.

Ying Y-W. Validation of the California Psychological Inventory Femininity Scale in Taiwan college graduates. J Multicult Couns Devel 1991;19(4):166-72.

Blake RJ, Potter EH 3d, Slimak RE. Validation of the structural scales of the CPI for predicting the performance of junior officers in the U.S. Coast Guard. J Bus Psychol 1993;7(4):431-48.

Collins JM, Schmidt FL. Personality, integrity, and white collar crime: a construct validity study. Person Psychol 1993;46(2):295-311.

Kadden RM, Litt MD, Donovan D, Cooney NL. Psychometric properties of the California Psychological Inventory Socialization scale in treatment-seeking alcoholics. Psychol Addict Behav 1996;10(3):131-46.

Sandal GM, Endresen IM. The sensitivity of the CPI Good Impression Scale for detecting 'faking good' among Norwegian students and job applicants. Int J Sel Assess 2002;10(4):304-11.

\section{Cancer Empowerment Questionnaire}

Shin SH, Park H. [Development and validation of the empowerment scale for women with breast cancer]. J Korean Acad Nurs 2015;45(4):613-24. Korean.

van den Berg SW, van Amstel FKP, Ottevanger PB, Gielissen MFM, Prins JB. The cancer empowerment questionnaire: psychological empowerment in breast cancer survivors. J Psychosoc Oncol 2013;31(5):565-83.

Custers JAE, van den Berg SW, van Laarhoven HWM, Bleiker EMA, Gielissen MFM, Prins JB. The Cancer Worry Scale: detecting fear of recurrence in breast cancer survivors. Cancer Nurs 2014;37(1):E44-50.

\section{Caregiver Well-Being Scale}

Tebb S. An aid to empowerment: a caregiver well-being scale. Health Soc Work 1995;20(2):87-92.

Rubio DM, Berg-Weger M, Tebb SS. Assessing the validity and reliability of well-being and stress in family caregivers. Soc Work Res 1999;23(1):54-64.

Berg-Weger M, Rubio DM, Tebb SS. The Caregiver Well-Being Scale revisited. Health Soc Work 2000;25(4):255-63.

Rubio DM, Berg-Weger M, Tebb SS, Lee ES, Rauch S. Objectifying content validity: conducting a content validity study in social work research. Soc Work Res 2003;27(2):94-104.

Tebb SS, Berg-Weger M, Rubio DM. The Caregiver Well-Being Scale: developing a short-form rapid assessment instrument. Health Soc Work 2013;38(4):222-30.

The opinions expressed by authors contributing to this journal do not necessarily reflect the opinions of the U.S. Department of Health and Human Services, the Public Health Service, the Centers for Disease Control and Prevention, or the authors' affiliated institutions. 
Demirtepe D, Bozo Õ. Bakici ıyilik ölçeği’nin uyarlama, güvenirlik ve geçerlik çalişması. Turk Psikol Yaz 2009;12(23)28-37.

\section{Chronic Illness Resources Survey}

Glasgow RE, Strycker LA, Toobert DJ, Eakin E. A social-ecologic approach to assessing support for disease self-management: the Chronic IIIness Resources Survey. J Behav Med 2000;23(6):559-83.

Eakin EG, Reeves MM, Bull SS, Riley KM, Floyd S, Glasgow RE. Validation of the Spanish-language version of the Chronic Illness Resources Survey. Int J Behav Med 2007;14(2):76-85.

\section{College Student Hardiness Measure}

Atri A, Sharma M, Cottrell R. Role of social support, hardiness, and acculturation as predictors of mental health among international students of Asian Indian origin. Int Q Community Health Educ 2006-2007;27(1):59-73.

\section{Connor-Davidson Resilience Scale}

Connor KM, Davidson JR. Development of a new resilience scale: the Connor-Davidson Resilience Scale (CD-RISC). Depress Anxiety 2003;18(2):76-82.

Baek H-S, Lee K-U, Joo E-J, Lee M-Y, Choi K-S. Reliability and validity of the Korean version of the Connor-Davidson Resilience Scale. Psychiatry Investig 2010;7(2):109-15.

Notario-Pacheco B, Martínez-Vizcaíno V, Trillo-Calvo E, Pérez-Yus MC, Serrano-Parra D, García-Campayo J. Validity and reliability of the Spanish version of the 10-item CD-RISC in patients with fibromyalgia. Health Qual Life Outcomes 2014;12(1):14.

Jeong HS, Kang I, Namgung E, Im JJ, Jeon Y, Son J, et al. Validation of the Korean version of the Connor-Davidson Resilience Scale-2 in firefighters and rescue workers. Compr Psychiatry 2015;59:123-8.

Sarubin N, Gutt D, Giegling I, Bühner M, Hilbert S, Krähenmann O, et al. Erste Analyse der psychometrischen Eigenschaften und Struktur der deutschsprachigen 10und 25-Item Version der Connor-Davidson Resilience Scale (CD-RISC). Z Gesundh psychol 2015;23(3):112-22.

Ni MY, Li TK, Yu NX, Pang H, Chan BH, Leung GM, et al. Normative data and psychometric properties of the Connor-Davidson Resilience Scale (CD-RISC) and the abbreviated version (CD-RISC2) among the general population in Hong Kong. Qual Life Res 2016;25(1):111-6.

Xie Y, Peng L, Zuo X, Li M. The psychometric evaluation of the Connor-Davidson resilience scale using a Chinese military sample. PLoS One 2016;11(2):e0148843.

\section{Dispositional Resilience Scale}

Hystad SW, Eid J, Johnsen BH, Laberg JC, Thomas Bartone P. Psychometric properties of the revised Norwegian dispositional resilience (hardiness) scale. Scand J Psychol 2010;51(3):237-45.

Picardi A, Bartone PT, Querci R, Bitetti D, Tarsitani L, Roselli V, et al. Development and validation of the Italian version of the 15-item dispositional resilience scale. Riv Psichiatr 2012;47(3):231-7.

Bartone PT. Predictors of stress-related illness in city bus drivers. J Occup Med 1989;31(8):657-63.

\section{Five-Factor Personality Inventory}

Hendriks AJ, Hofstee WK, De Raad B. The Five-Factor Personality Inventory (FFPI). Pers Individ Dif 1999;27(2):307-25.

Buchanan T, Johnson JA, Goldberg LR. Implementing a five-factor personality inventory for use on the internet. Eur J Psychol Assess 2005;21(2):115-27.

Perugini M, Ercolani AP. Validity of the five factor personality inventory (FFPI): an investigation in Italy. Eur J Psychol Assess 1998;14(3):234-48.

Marshall GN, Wortman CB, Vickers RR Jr, Kusulas JW, Hervig LK. The five-factor model of personality as a framework for personality-health research. J Pers Soc Psychol 1994;67(2):278-86.

Salgado JF. The Five Factor Model of personality and job performance in the European Community. J Appl Psychol 1997;82(1):30-43.

The opinions expressed by authors contributing to this journal do not necessarily reflect the opinions of the U.S. Department of Health and Human Services, the Public Health Service, the Centers for Disease Control and Prevention, or the authors' affiliated institutions. 
Rodríguez-Fornells A, Lorenzo-Seva U, Andrés-Pueyo A. Psychometric properties of the Spanish adaptation of the Five Factor Personality Inventory. Eur J Psychol Assess 2001;17(2):145-53.

Hendriks AJ, Hofstee WK, Raad BD. The five-factor personality inventory (FFPI). Pers Individ Dif 1999;27(2):307-25.

Somer O, Korkmaz M, Tatar A. Bes Faktör Kisilik Envanteri'nin Gelistirilmesi-l: Ôlçek ve Alt Ôlçeklerin Olugturulmasi. Turk Psikol Derg 2002;17(49):21-33.

Araz A, Erkus A. Duygu Disavurum Tarzlarinin Kavramsallastirilmasi ve Ölçümü: Bir Envanter Gelistirme Çalismasi. Turk Psikol Derg 2014;29(74):50-61.

Fruyt FD, McCrae RR, Szirmák Z, Nagy J. The five-factor personality inventory as a measure of the five-factor model: Belgian, American, and Hungarian comparisons with the NEO-PI-R. Assessment 2004;11(3):207-15.

Sharma S, Deller J, Biswal R, Mandal MK. Emotional intelligence: factorial structure and construct validity across cultures. Int J Cross Cult Manag 2009;9(2):217-36.

\section{Inner Strength Questionnaire}

Roux G, Lewis K, Younger J, Dingley C. Development and testing of the inner strength questionnaire. J Cult Divers 2003;10(1):4-5.

Lewis KL, Roux G. Psychometric testing of the Inner Strength Questionnaire: women living with chronic health conditions. Appl Nurs Res 2011;24(3):153-60.

\section{Interpersonal Support Evaluation List}

Brookings JB, Bolton B. Confirmatory factor analysis of the Interpersonal Support Evaluation List. Am J Community Psychol 1988;16(1):137-47.

Schonfeld IS, Ruan D. Occupational stress and preemployment measures of depressive symptoms: The case of teachers. J Soc Behav Pers 1991;6(7):95.

Bates DS. Cross-sectional and longitudinal analyses of two measures of social support among the homeless [dissertation]. Buffalo (NY): State University of New York at Buffalo; 1995.

Bates DS, Toro PA. Developing measures to assess social support among homeless and poor people. J Community Psychol 1999;27(2):137-56.

McColl MA, Skinner H. Assessing inter- and intrapersonal resources: social support and coping among adults with a disability. Disabil Rehabil 1995;17(1):24-34.

Rintala DH. Predictive validity of social support relative to psychological well-being in men with spinal cord injury. Rehabil Psychol 2013;58(4):422-8.

Bastardo YM, Kimberlin CL. Relationship between quality of life, social support and disease-related factors in HIV-infected persons in Venezuela. AIDS Care 2000;12(5):673-84.

Delistamati E, Samakouri MA, Davis EA, Vorvolakos T, Xenitidis K, Livaditis M. Interpersonal Support Evaluation List (ISEL) - college version: validation and application in a Greek sample. Int J Soc Psychiatry 2006;52(6):552-60.

Szlachta E. The adaptation and preliminary validation of the Polish version of the Interpersonal Support Evaluation List (ISEL). Prz Psychol 2009;52(4):433-51.

Baumann M, Lurbe K, Leandro M-E, Chau N. Life satisfaction of two-year post-stroke survivors: effects of socio-economic factors, motor impairment, Newcastle stroke-specific quality of life measure and World Health Organization quality of life: bref of informal caregivers in Luxembourg and a rural area in Portugal. Cerebrovasc Dis 2012;33(3):219-30.

Mendoza F, Bastardo Y. PIH68 quality of life and social support among college students in Venezuela. Value Health 2012;15(4):A204.

Moretti M, Simonelli A, Melloni M, Ronconi L. Interpersonal Support Evaluation List (ISEL): validation and application in an Italian sample. Psicol Soc 2012;(3):447-57.

Merz EL, Roesch SC, Malcarne VL, Penedo FJ, Llabre MM, Weitzman OB, et al. Validation of Interpersonal Support Evaluation List-12 (ISEL-12) scores among English- and Spanish-speaking Hispanics/Latinos from the HCHS/SOL Sociocultural Ancillary Study. Psychol Assess 2014;26(2):384-94.

Sacco E, Bientinesi R, Marangi F, D'Addessi A, Racioppi M, Gulino G, et al. [Overactive bladder syndrome: the social and economic perspective]. Urologia 2011;78(4):241-56. Italian.

The opinions expressed by authors contributing to this journal do not necessarily reflect the opinions of the U.S. Department of Health and Human Services, the Public Health Service, the Centers for Disease Control and Prevention, or the authors' affiliated institutions. 


\section{Life Attitude Profile}

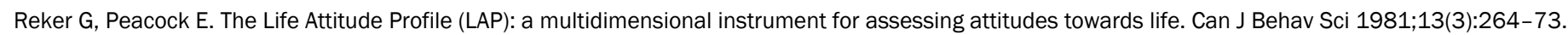

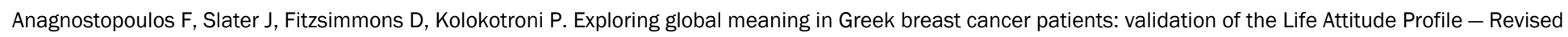
(LAP-R). Psychooncology 2011;20(4):419-27.

\section{Mental Toughness Questionnaire (MTQ48)}

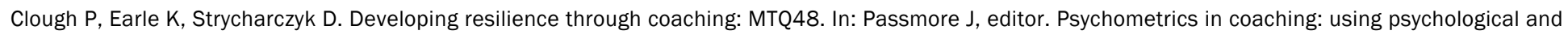
psychometric tools for development. London (GB): Kogan Page; 2008. p. 208-23.

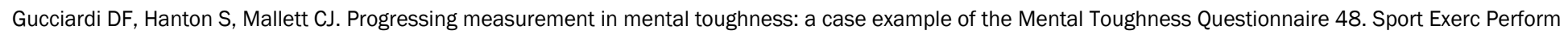
Psychol 2012;1(3):194-214.

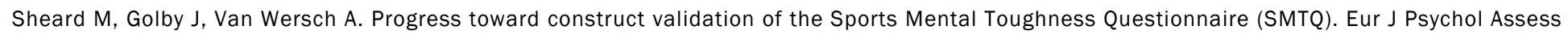
2009;25(3):186-93.

Perry JL, Clough PJ, Crust L, Earle K, Nicholls AR. Factorial validity of the mental toughness questionnaire-48. Pers Individ Dif 2013;54(5):587-92.

\section{Norbeck Social Support Questionnaire}

Norbeck JS, Lindsey AM, Carrieri VL. The development of an instrument to measure social support. Nurs Res 1981;30(5):264-9.

La Roche MJ, Turner C, Kalick SM. Latina mothers and their toddlers' behavioral difficulties. Hisp J Behav Sci 1995;17(3):375-84.

\section{Post Traumatic Growth Inventory}

Tedeschi RG, Calhoun LG. The Posttraumatic Growth Inventory: measuring the positive legacy of trauma. J Trauma Stress 1996;9(3):455-71.

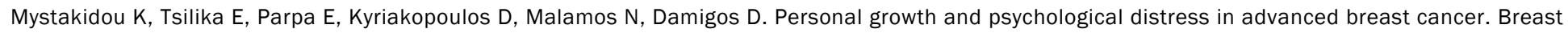
2008;17(4):382-6.

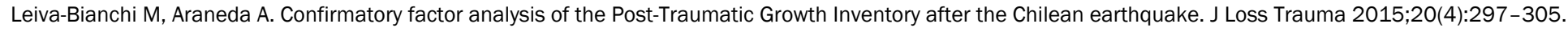

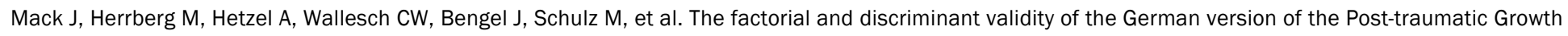
Inventory in stroke patients. Neuropsychol Rehabil 2015;25(2):216-32.

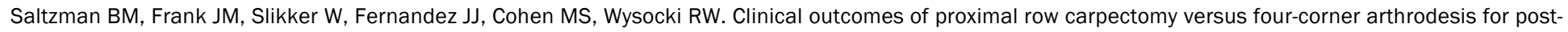
traumatic wrist arthropathy: a systematic review. J Hand Surg Eur Vol 2015;40(5):450-7.

\section{Psychological Capital Questionnaire}

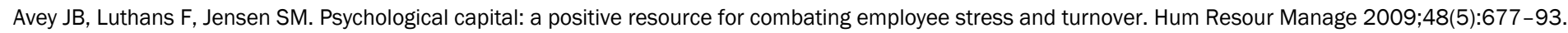

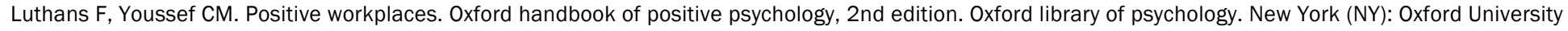
Press; 2009. p. 579-88.

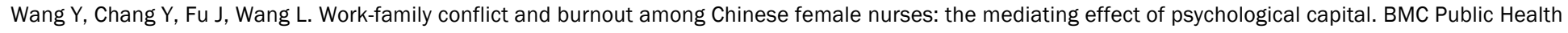
2012;12(1):915.

\section{Psychological Well-being Questionnaire}

Ryff CD, Keyes CLM. The structure of psychological well-being revisited. J Pers Soc Psychol 1995;69(4):719-27.

\section{Resilience Scale for Adults}

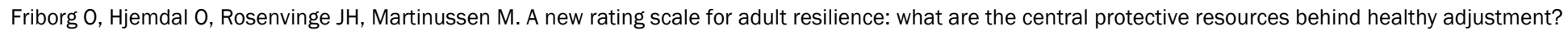

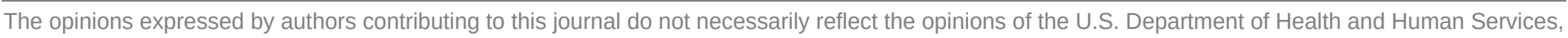
the Public Health Service, the Centers for Disease Control and Prevention, or the authors' affiliated institutions. 
Int J Methods Psychiatr Res 2003;12(2):65-76.

Friborg O, Barlaug D, Martinussen M, Rosenvinge JH, Hjemdal O. Resilience in relation to personality and intelligence. Int J Methods Psychiatr Res 2005;14(1):29-42.

Friborg $\mathrm{O}$, Martinussen M, Rosenvinge $\mathrm{JH}$. Likert-based vs. semantic differential-based scorings of positive psychological constructs: a psychometric comparison of two versions of a scale measuring resilience. Pers Individ Dif 2006;40(5):873-84.

Jowkar B, Friborg O, Hjemdal O. Cross-cultural validation of the Resilience Scale for Adults (RSA) in Iran. Scand J Psychol 2010;51(5):418-25.

Hjemdal O, Friborg O, Braun S, Kempenaers C, Linkowski P, Fossion P. The Resilience Scale for Adults: construct validity and measurement in a Belgian sample. Int J Test 2011;11(1):53-70.

Hilbig J, Viliūnienè R, Friborg O, Pakalniškienè V, Danilevičiūtè V. Resilience in a reborn nation: validation of the Lithuanian Resilience Scale for Adults (RSA). Compr Psychiatry 2015;60:126-33.

Hjemdal O, Roazzi A, Dias MG, Friborg O. The cross-cultural validity of the Resilience Scale for Adults: a comparison between Norway and Brazil. BMC Psychol 2015;3(1):18.

\section{Resistance to Trauma Test}

Urra Portillo J, Escorial Martín S, Martínez Arias R. Development and psychometric properties of the Resistance to Trauma Test (TRauma). Psicothema 2014;26(2):215-21.

\section{Response to Stressful Experiences Scale}

Johnson DC, Polusny MA, Erbes CR, King D, King L, Litz BT, et al. Development and initial validation of the Response to Stressful Experiences Scale. Mil Med 2011;176(2):161-9.

\section{Sense of Coherence Scale}

Eriksson M, Lindström B. Validity of Antonovsky's sense of coherence scale: a systematic review. J Epidemiol Community Health 2005;59(6):460-6.

\section{Solution-Focused Inventory}

Grant AM, Cavanagh MJ, Kleitman S, Spence G, Lakota M, Yu N. Development and validation of the Solution-Focused Inventory. J Posit Psychol 2012;7(4):334-48.

Yang H, Hai T. Reliability and validity of the Chinese version of the solutionfocused inventory in college students. J Multicult Couns Devel 2015;43(4):305-15.

\section{Values in Action}

Macdonald C, Bore M, Munro D. Values in action scale and the big 5: an empirical indication of structure. J Res Pers 2008;42(4):787-99.

Azañedo CM, Fernández-Abascal EG, Barraca J. Character strengths in Spain: validation of the Values in Action Inventory of Strengths (VIA-IS) in a Spanish sample. Clin Salud 2014;25(2):123-30.

Choubisa R, Singh K. Psychometrics encompassing VIA-IS: a comparative cross cultural analytical and referential reading. J Indian Acad Appl Psychol 2011;37(2):325-32.

Duan W, Bai Y, Tang X, Siu PY, Ho S. Virtues and positive mental health. Ment Health (Lond) 2012;38(2):1-8.

Duan W, Ho SM, Yu B, Tang X, Zhang Y, Li T, et al. Factor structure of the Chinese Virtues Questionnaire. Res Soc Work Pract 2012;22(6):680-8.

Khumalo IP, Wissing MP, Temane QM. Exploring the validity of the Values-In-Action Inventory of Strengths (VIA-IS) in an African context. J Psychol Afr 2008;18(1):133-42.

Littman-Ovadia H. The effect of client attachment style and counselor functioning on career exploration. J Vocat Behav 2008;73(3):434-9.

The opinions expressed by authors contributing to this journal do not necessarily reflect the opinions of the U.S. Department of Health and Human Services, the Public Health Service, the Centers for Disease Control and Prevention, or the authors' affiliated institutions. 
Otake K, Shimai S, Ikemi A, Utsuki N, Peterson C, Seligman ME. [Development of the Japanese version of the Values In Action Inventory of Strengths (VIA-IS)]. Shinrigaku Kenkyu 2005;76(5):461-7. 